San Jose State University

SJSU ScholarWorks

Master's Theses

Master's Theses and Graduate Research

1993

\title{
Origin of sediment ripple bands and zones on the inner shelf of southern Monterey Bay, California
}

Judy J. Mariant

San Jose State University

Follow this and additional works at: https://scholarworks.sjsu.edu/etd_theses

\section{Recommended Citation}

Mariant, Judy J., "Origin of sediment ripple bands and zones on the inner shelf of southern Monterey Bay, California" (1993). Master's Theses. 700.

DOI: https://doi.org/10.31979/etd.4h9b-gnpa

https://scholarworks.sjsu.edu/etd_theses/700

This Thesis is brought to you for free and open access by the Master's Theses and Graduate Research at SJSU ScholarWorks. It has been accepted for inclusion in Master's Theses by an authorized administrator of SJSU ScholarWorks. For more information, please contact scholarworks@sjsu.edu. 


\section{INFORMATION TO USERS}

This manuscript has been reproduced from the microfilm master. UMI films the text directly from the original or copy submitted. Thus, some thesis and dissertation copies are in typewriter face, while others may be from any type of computer printer.

The quality of this reproduction is dependent upon the quality of the copy submitted. Broken or indistinct print, colored or poor quality illustrations and photographs, print bleedthrough, substandard margins, and improper aligument can adversely affect reproduction.

In the unlikely. event that the author did not send UMI a complete manuscript and there are missing pages, these will be noted. Also, if unauthorized copyright material had to be removed, a note will indicate the deletion.

Oversize materials (e.g., maps, drawings, charts) are reproduced by sectioning the original, beginning at the upper left-hand corner and continuing from left to right in equal sections with small overlaps. Each original is also photographed in one exposure and is included in reduced form at the back of the book.

Photographs included in the original manuscript have been reproduced xerographically in this copy. Higher quality $6 "$ x 9 " black and white photographic prints are available for any photographs or illustrations appearing in this copy for an additional charge. Contact UMI directly to order.

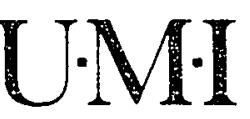

University Microfilms International

A Bell \& Howell information Company

300 North Zeeb Road. Ann Arbor. M1 48106-1346 USA

313/761-4700 800:521-0600 

Order Number 1356483

Origin of sediment ripple bands and zones on the inner shelf of southern Monterey Bay, California

\author{
Mariant, Judy J., M.S.
}

San Jose State University, 1993 


\title{
ORIGIN OF SEDIMENT RIPPLE BANDS AND ZONES \\ ON THE INNER SHELF OF SOUTHERN MONTEREY BAY, CALIFORNIA
}

\author{
A Thesis \\ Presented to San Jose State University \\ In Partial Fulfillment \\ of the Requirements for the Degree \\ Master of Science in Geology
}

BY

Judy J. Mariant

December, 1993 
(C) 1993

Judy J. Mariant

ALL RIGHTS RESERVED 
APPROVED FOR GEOLOGY DEPARTMENT

Mine J. Ledotes

Dr. Michael T. Ledbetter

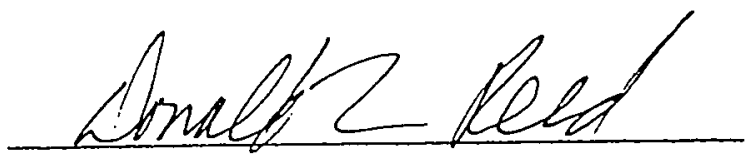

Dr. Don Reed

Willow Buran

Dr. William W. Broenkow

APPROVED FOR THE UNIVERSITY

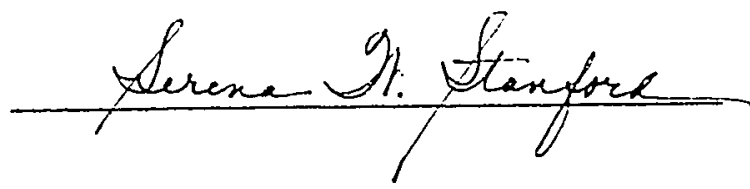




\section{ACKNOWLEDGEMENTS}

I would like to thank Dr. Michael T. Ledbetter for getting me started on this project and pushing me through it on my geological time schedule (very slow and steady). I would also like to thank Dr. W.W. Broenkow and Dr. Don Reed for being my thesis advisors.

This would not have been possible without the help of all of the staff at Moss Landing Marine Laboratories. Those who stand out most are: Tracy Thomas who patiently piloted the R/V Ed Ricketts for three of my cruises; Mike Prince who captained my last cruise; John Heine and his dive assistant, who pulled cores for me; the people at marine operations who help with arranging cruise schedules and equipment use; Lynn McMasters for her assistance and creative ideas for my illustrations; my fellow students who helped manhandle the equipment when loading and unloading the Ricketts and functioned as human winches for the towfish; last but not least my two fellow geology students whose moral support helped me plod on with this project.

Most important of all I would like to thank my husband Jay F. Mariant for putting up with me while I was taking classes and preparing my thesis. 
TABLE OF CONTENTS

ABSTRACT $\ldots \ldots \ldots \ldots \ldots \ldots \ldots \ldots \ldots \ldots \ldots \ldots \ldots \ldots \ldots \ldots \ldots \ldots \ldots \ldots$

INTRODUCTION $\ldots \ldots \ldots \ldots \ldots \ldots \ldots \ldots \ldots \ldots \ldots \ldots \ldots \ldots \ldots \ldots \ldots$

Geologic setting $\ldots \ldots \ldots \ldots \ldots \ldots \ldots \ldots \ldots \ldots \ldots \ldots \ldots \ldots \ldots$

Currents and circulation $\ldots \ldots \ldots \ldots \ldots \ldots . \ldots . \ldots$

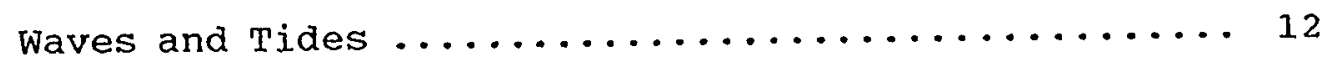

Nearshore Circulation .................... 14

Nearshore Sedimentary Processes .............. 16

METHODS $\ldots \ldots \ldots \ldots \ldots \ldots \ldots \ldots \ldots \ldots \ldots \ldots \ldots \ldots \ldots \ldots \ldots$

Side Scan Sonar Data $\ldots \ldots \ldots \ldots \ldots \ldots \ldots \ldots \ldots \ldots$

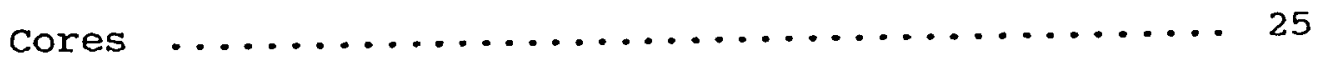

Aerial Photos ............................ 25

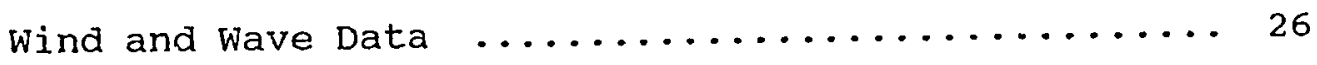

DATA PRESENTATION $\ldots \ldots \ldots \ldots \ldots \ldots \ldots \ldots \ldots \ldots \ldots \ldots \ldots$

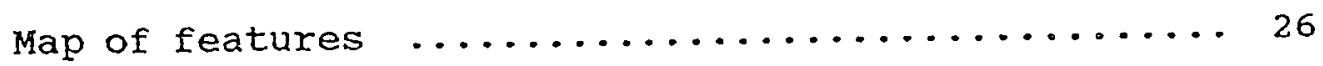

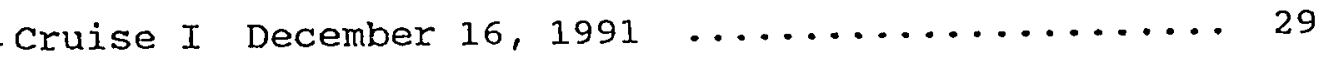

Cruise II February $2,1992 \ldots \ldots \ldots \ldots \ldots \ldots \ldots \ldots . \ldots . \ldots . \ldots$

Cruise III April $27,1992 \ldots \ldots \ldots \ldots \ldots \ldots \ldots \ldots \ldots$

Longitudinal Ridges $\ldots \ldots \ldots \ldots \ldots \ldots \ldots \ldots \ldots \ldots \ldots$

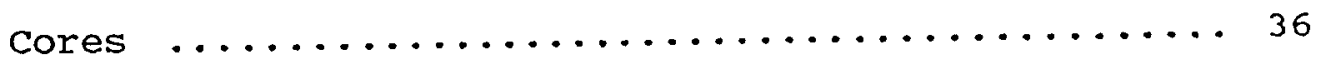

Aerial Photographs $\ldots \ldots \ldots \ldots \ldots \ldots \ldots \ldots \ldots \ldots \ldots \ldots . \ldots \ldots$ 


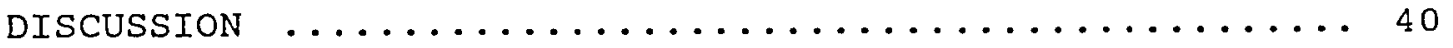

CONCLUSIONS $\ldots \ldots \ldots \ldots \ldots \ldots \ldots \ldots \ldots \ldots \ldots \ldots \ldots$

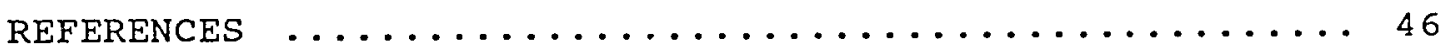

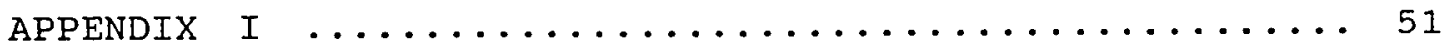

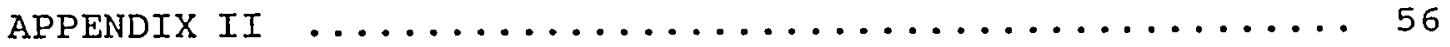




\section{LIST OF FIGURES}

Fig. 1 Location of Rippled zones and bands .......... 2

Fig. 2 sonographs of rippled zones and bands ........ 3

Fig. 3 Salinian Block, blocks and basins ......... 6

Fig. 4 Monterey Bay Dune Complex $\ldots \ldots \ldots \ldots \ldots \ldots \ldots \ldots$

Fig. $\quad 5$ Beach grain size and location .............. 10

Fig. 6 Aerial photo of rip cells $\ldots \ldots \ldots \ldots \ldots \ldots \ldots \ldots 1$

Fig. 7 Directions of approach and wave refraction $\ldots . .13$

Fig. 8 Rip current cells and longshore transport ..... 15

Fig. 9 Southern Monterey Bay littoral cell $\ldots \ldots \ldots \ldots . .17$

Fig. 10 Bedform stability and orbital motion ......... 18

Fig. 11 Rip current morphology $\ldots \ldots \ldots \ldots \ldots \ldots \ldots \ldots \ldots$

Fig. 12 Maps of rippled bands and zones $\ldots \ldots \ldots \ldots \ldots 27$

Fig. 13 Ripple spacing diagram $\ldots \ldots \ldots \ldots \ldots \ldots \ldots \ldots \ldots$

Fig. 14 Sonogram from cruise on December $16,1991 \ldots \ldots 29$

Fig. 15 Threshold velocity for sediment motion ....... 31

Fig. 16 . Sonogram from cruise on February 2, $1992 \ldots \ldots 32$

Fig. 17 Sonogram from cruise on April 17, $1992 \ldots \ldots \ldots 34$

Fig. 18 sonogram of longitudinal ridges $\ldots \ldots \ldots \ldots \ldots . \ldots 35$

Fig. 19 spacing of longitudinal ridges ........... 37

Fig. 20 Core stratigraphy and grain size ........... 38 


\section{LIST OF TABLES}

Table 1. Erosion Rates for Southern Monterey Bay ....... 4

viii 


\section{ABSTRACT}

The Southern Monterey Bay is an entire littoral cell characterized by a series of rip-currents, a weak southwardflowing longshore current caused by wave action, and a weak offshore current near Monterey. Shore-normal zones and shoreparallel bands of rippled coarse-grained sediments are found throughout Monterey Bay. These features are 1-1.5 km offshore in water depths of 10-30 $\mathrm{m}$ with wavelengths of $0.5-3.0 \mathrm{~m}$ and wave heights of $0.16-1.50 \mathrm{~m}$.

A series of side-scan mosaics constructed with multiple track lines reveal seasonal variations in the geometry of the rippled bands and zones. The tendency for ripple spacing to increase with decreasing depth indicates that large symmetrical ripples are oscillatory wave ripples, with spacing proportional to the diameter of orbital wave motion (clifton and Dingler, 1984).

Offshore currents aligned along the shore-normal zones were inferred from deviations in velocity and course changes in the R.V. Ricketts. Aerial photos show that shore-normal zones of ripples coincide with sites of rip currents that transport the sediment offshore during times of heavy surf activity

The bands are lag deposits that are located in scoured depressions, presumably formed during storms, and represent temporary offshore depocenters of coarse-grained sediment. 


\section{INTRODUCTION}

Shore-normal zones and shore-parallel bands of rippled heds of coarse-grained sand are located throughout Monterey Bay (Fig. 1 \& 2). These features are 1.0-1.5 km offshore in water depths of 10-60 m. Ripple wave lengths vary from 0.5 to $3.0 \mathrm{~m}$ and the wave heights are approximately 0.2 to $2.0 \mathrm{~m}$. The source of the sand in these bands and zones is beach, back beach and dune erosion.

In 1983 up to $2.59 \mathrm{~m}$ of erosion occurred during one significant storm season (Griggs \& Jones, 1985, Table 1). As sea level continues to rise, erosion, offshore transport and offshore deposition rates will continue to be high and could increase. Several environmental factors contribute to the observed coastal erosion, including offshore sediment transport, regional tectonics, distribution of geologic formations, nearshore circulation patterns, and the intensity and direction of wave patterns.

The purposes of this study are: 1) to determine if there is a seasonal or storm-induced migration of these bedforms, 2) to apply wave theory to wave and current data collected in Monterey Bay in order to explain the rippled features by comparing models that relate bedforms to ripple geometry, wave conditions, and grain size, and 3) to examine rip currents, storm induced downwelling and currents generated by wind and wave action as a potential mechanism of offshore sediment transport. 


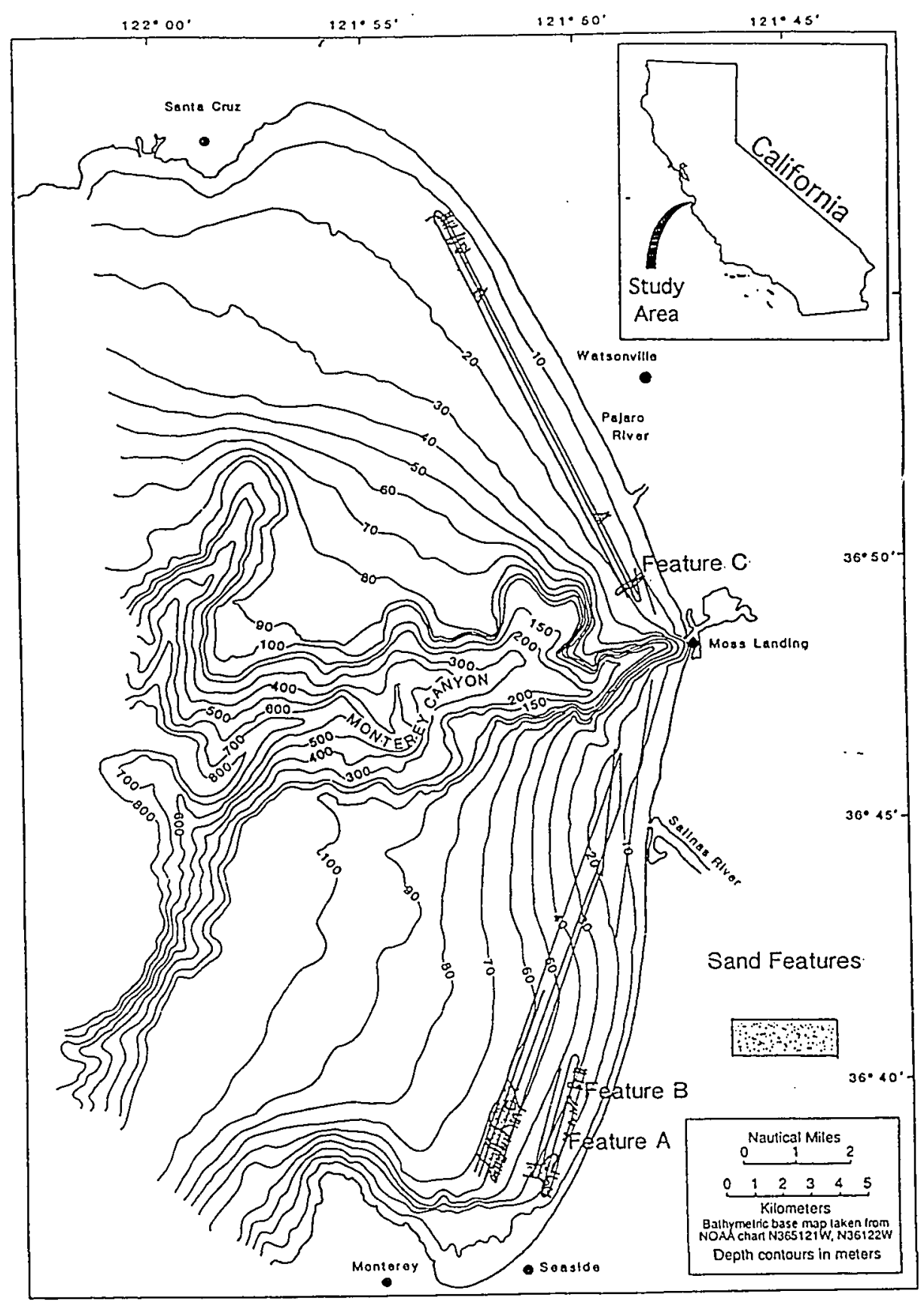

Figure 1. Location of navigation lines, rippled zones and bands of coarse sand shown on side-scan sonar taken in 1989 and 1990. Sonograms of feature $A, B$ and $C$ are shown on figure 2 . 


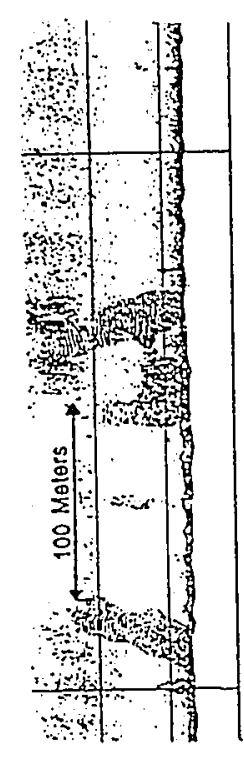

Feature A
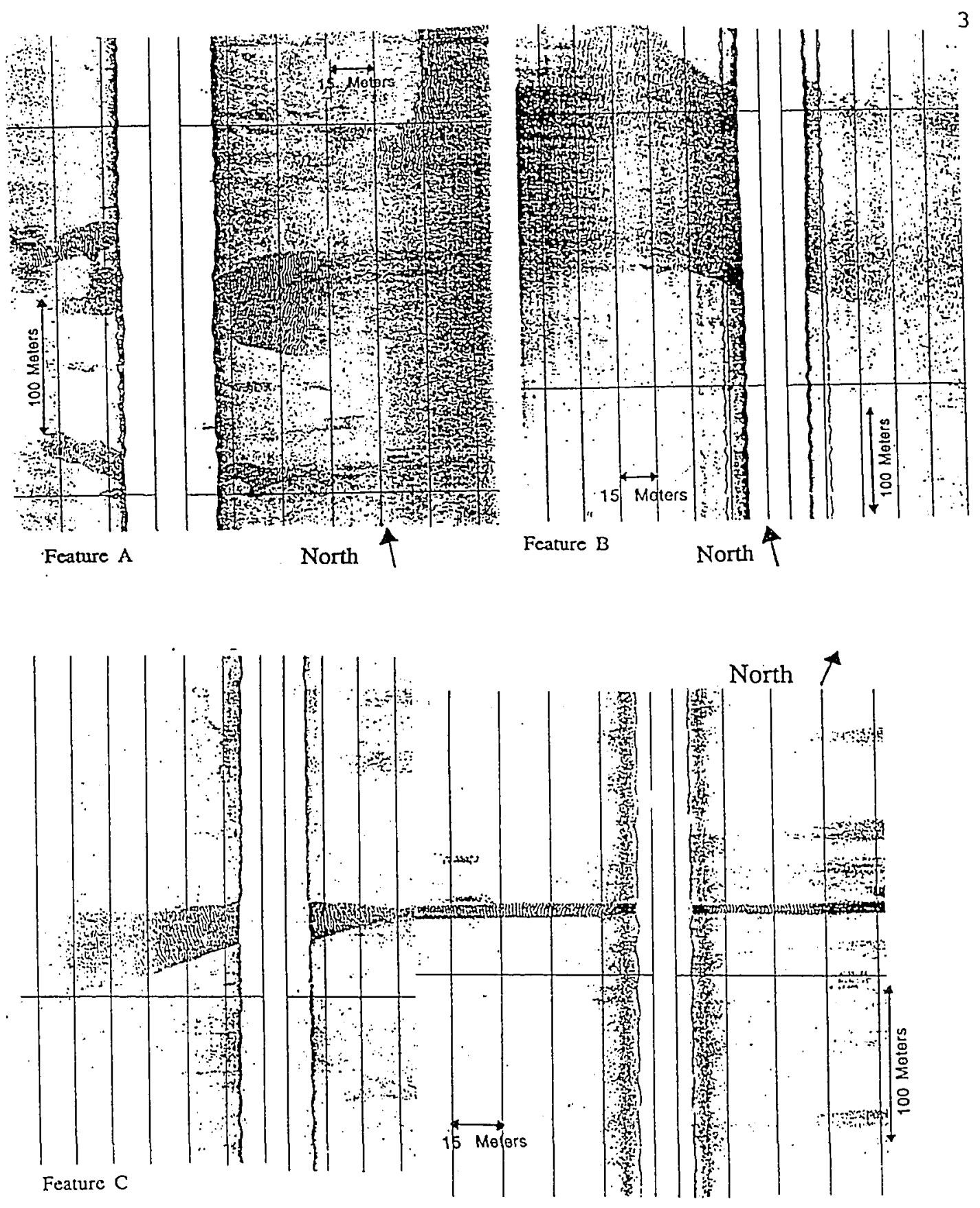

Figure 2.

Sonographs of rippled coarse grained features shown on figure 1 . $A$. is a sonograph of $a$ patchy rippled band. large rippled band. $C$. is a sonograph of a $B$. is a sonograph of a rippled shore-normal zone. Locations of $A, B$, and $C$ are shown on figure 1. 
Table 1. Shoreline Erosion Rates for Southern Monterey Bay

\begin{tabular}{|c|c|c|c|}
\hline Location & time span & $\mathrm{m} / \mathrm{yr}$ & reference cited \\
\hline Marina & $1937-1983$ & $1.7-1.8$ & Jones (1983) \\
\hline Marina & $1937-1986$ & $1.1-1.5$ & Johnson et al. (1987) \\
\hline Marina & $1915-1986$ & $0.8-3.0$ & Griggs \& Savoy (1985) \\
\hline Fort Ord & $1956-1983$ & $3.6-4.6$ & Arnal et al. (1973) \\
\hline Fort Ord & $1920-1973$ & $0.4-1.5$ & Arnal et al. (1973) \\
\hline Fort Ord & 1950 's & 0.9 & Arnal et al. (1973) \\
\hline Fort Ord & 1960 's & 1.5 & Arnal et al. (1973) \\
\hline Fort Ord & & $1.8-2.6$ & Smith (1983) \\
\hline Fort Ord & $1920-1985$ & $1.9-2.6$ & Griggs \& Savoy (1985) \\
\hline Sand City & $1932-1983$ & $1.2-1.9$ & Jones (1983) \\
\hline Sand City & $1932-1970$ & $0.4-0.8$ & Welday (1972) \\
\hline Sand City & $1946-1967$ & $1.2-3.0$ & Griggs \& Savoy (1985) \\
\hline Monterey & $1939-1978$ & $0.3-0.5$ & Thompson (1981) \\
\hline Monterey & $1958-1983$ & $0.3-0.5$ & Jones (1983) \\
\hline Del Monte Beach & $1956-1984$ & 0.4 & Griggs \& Savoy (1985) \\
\hline
\end{tabular}

Table 1. Shoreline erosion rates for southern Monterey Bay. Erosion rates represent the landward migration of the shoreline, are shown in meters per year and have been collected from the references cited on the table. 
Geologic setting

Monterey Bay is the largest open embayment (Fig. 1) on the california coast and it is characterized by a wide shelf split by the Monterey Canyon. The bay is $40 \mathrm{~km}$ long in a north-south direction and extends to the edge of the continental shelf, which is less than $20 \mathrm{~km}$ west of the bay's eastern shore. Southern Monterey Bay extends from the head of the Monterey submarine canyon at Moss Landing southward to the Monterey Peninsula. The southern shelf slopes gently $\left(1-2.0^{\circ}\right)$ seaward, with bathymetric contours that are approximately parallel to the shoreline. Isobaths from depths of 70 meters and inland reflect the U-shaped shoreline of the southern end of the bay.

The Monterey Bay area is divided into smaller blocks and basins that are separated by southeast-northwest trending faults. Basin development within the salinan block began sometime in the Neogene and is continuing to the present (Greene, 1977). Uplift and subsidence of crustal blocks in this region is believed to result from wrench fault tectonics. The Salinas Block (Fig. 3) is affected by a broad tectonic downwarp. Based upon sediment thickness, Dupre (1975) and Tinsley (1975) suggest that the southern Monterey Bay has been continuously subsiding throughout the Quaternary. Rising eustatic sea-level and tectonic subsidence combine to cause a 


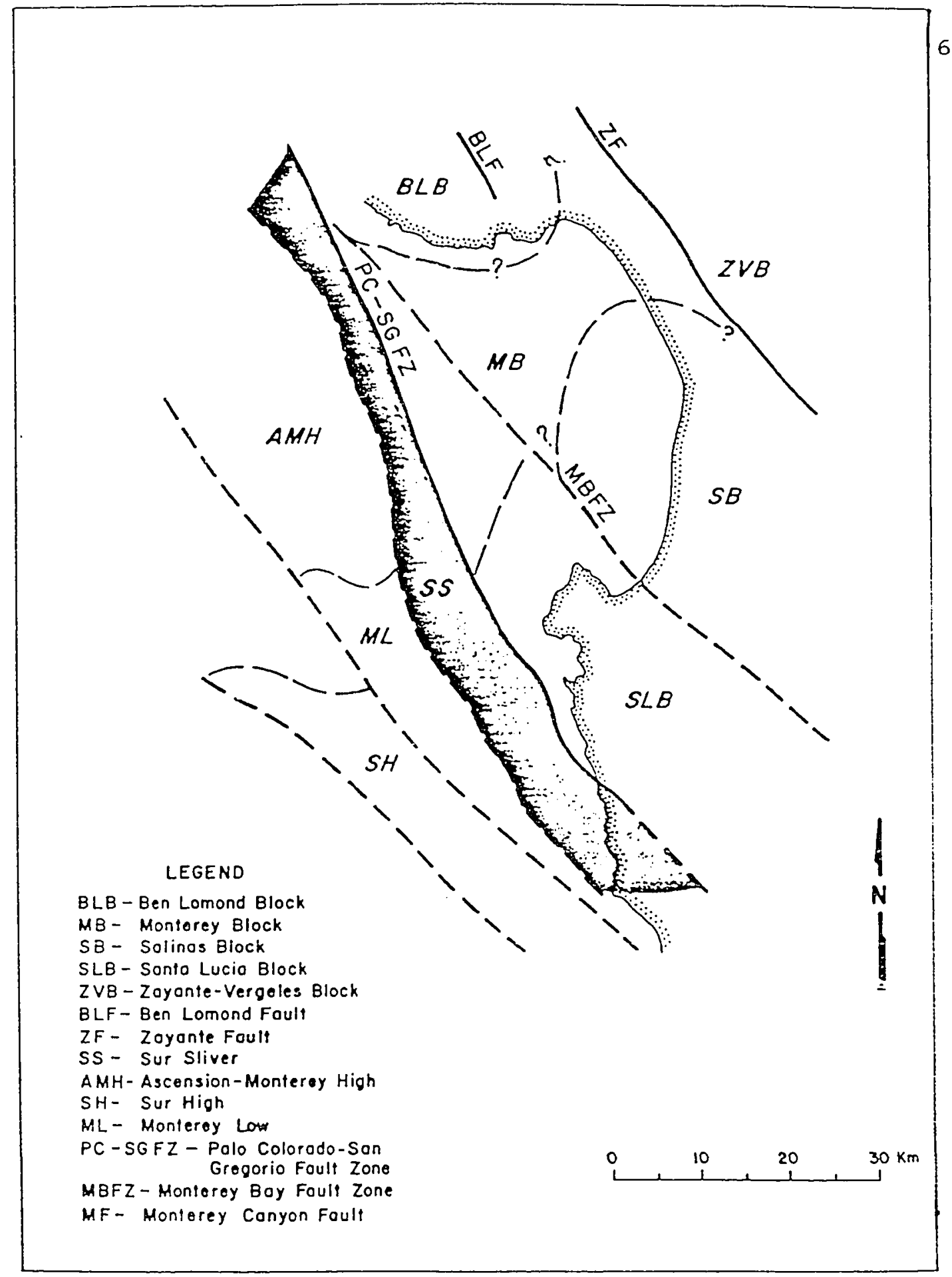

Figure 3 .

Map showing the divisions of the Salinian Block into the various blocks and basins that are separated by southeast-northeast trending faults. (from Greene et al., 1977) 
regional sea-level rise in the area.

The downwarped Salinas Block forms a topographic basin. During the last glacial low stand of sea level that peaked at $18 \mathrm{kya}$ (Dupre and Clifton 1979), an abundant supply of sand in the area initially formed broad flat beaches. Dry sand on the back beach was blown inland by the prevailing northwesterly winds, initially forming a backshore berm or foredune. The high sand supply in the region produced a series of dunes during the wisconsinian and pre-Wisonsinian called the Monterey dune complex (Cooper, 1967) that extends from Moss Landing to the Monterey Harbor. The dune complex consists of three geological units: 1) recent dunes that fringe the shoreline near the Salinas River, 2) wisconsin dunes that form a narrow belt along the coast from the salinas River to Monterey, and 3) pre-wisconsin dunes extending from the Salinas River to Monterey and inland up to 7 miles (Fig. 4). The recent dune belt formed as older dunes were eroded and reworked in response to eustatic sea-level rise beginning after the last glacial low stand 18 kya (Cooper, 1967). From Monterey harbor to the tip of Monterey Peninsula the shoreline consists of outcrops of granodiorite. The granodiorite is highly resistant to erosion and forms the rocky promontories of the Monterey Peninsula. Interspersed between these rocky promontories are a series of small sandy pocket beaches. The beaches from the Salinas River to 


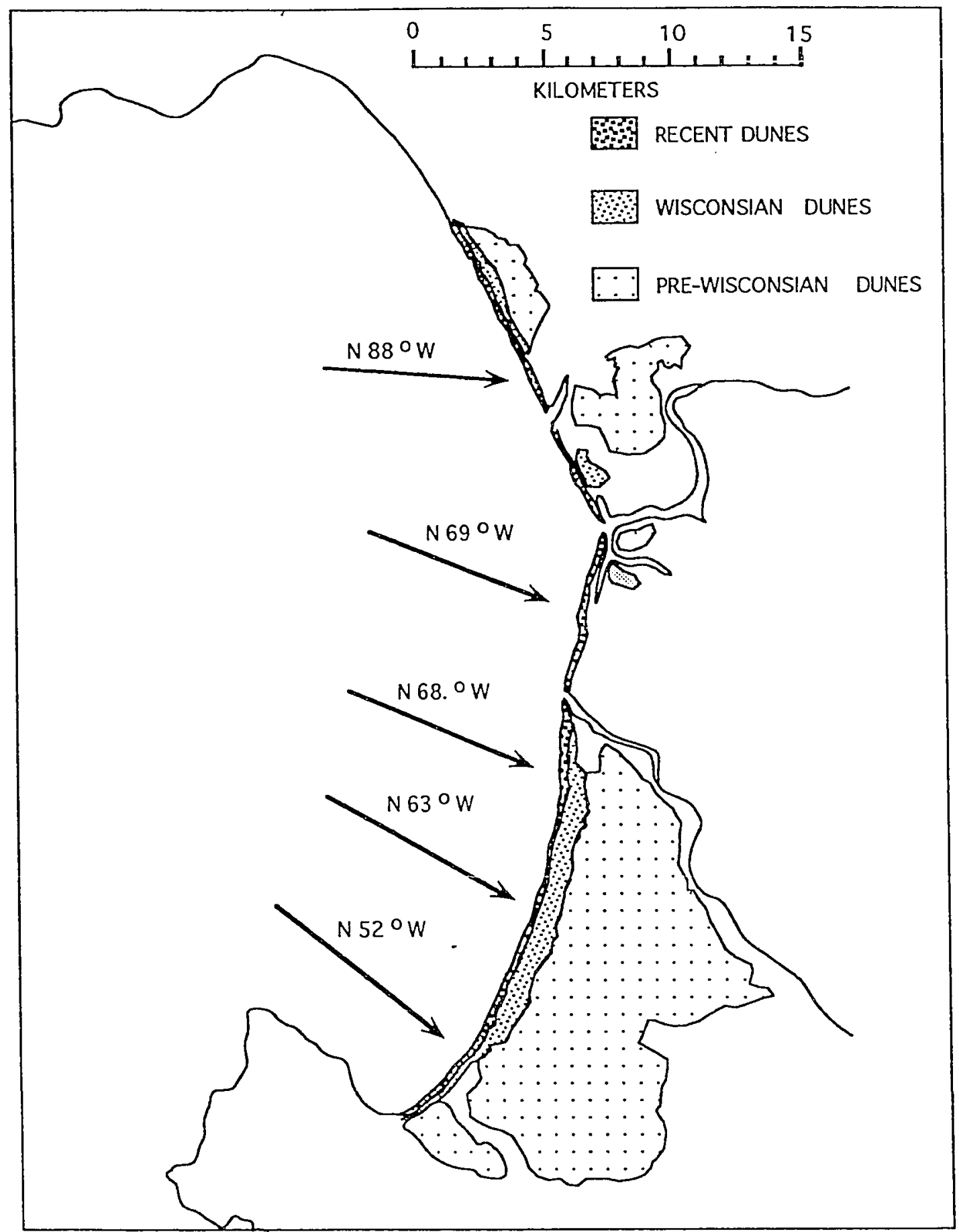

Figure 4.

Monterey Bay Dune Complex showing the Recent, Wisconsin, and Pre-Wisconsin dunes and the prevailing wind direction. (after Cooper 1967) 
Monterey are narrow, and subject to high-energy wave impact (Chin, et al., 1988). The coarse-grained material (Fig. 5) of these beaches has been derived from ancient beach and offshore deposits uncovered by erosion of the overlying dune deposits. site inspections and aerial photographic studies of the beaches have identified a rhythmic topography consisting of a series of beach cusps and troughs which run offshore at an oblique angle (Fig. 6).

currents and circulation

Circulation in Monterey Bay is strongly influenced by the circulation patterns larther off the coast. The available information on the central California coast indicates a complex circulation system. Breaker and Broenkow (1989) surmised that the combination of the offshore currents and submarine topography sets up the general circulation patterns of water in the southern portion of the bay. Coastal upwelling often starts abruptly in the spring north and south of Monterey Bay; upwelled water from those areas may be advected into the Bay. Offshore upwelling occasionally occurs across the entrance of Monterey Bay between March and October. onshore flow in the Monterey Canyon is consistent with bathymetrically induced upwelling, where cold saline water follows the slopes of the canyon up to the head and then spreads out over the shelf areas. Seasonal changes in the deep circulation may be related to variations in the strength 

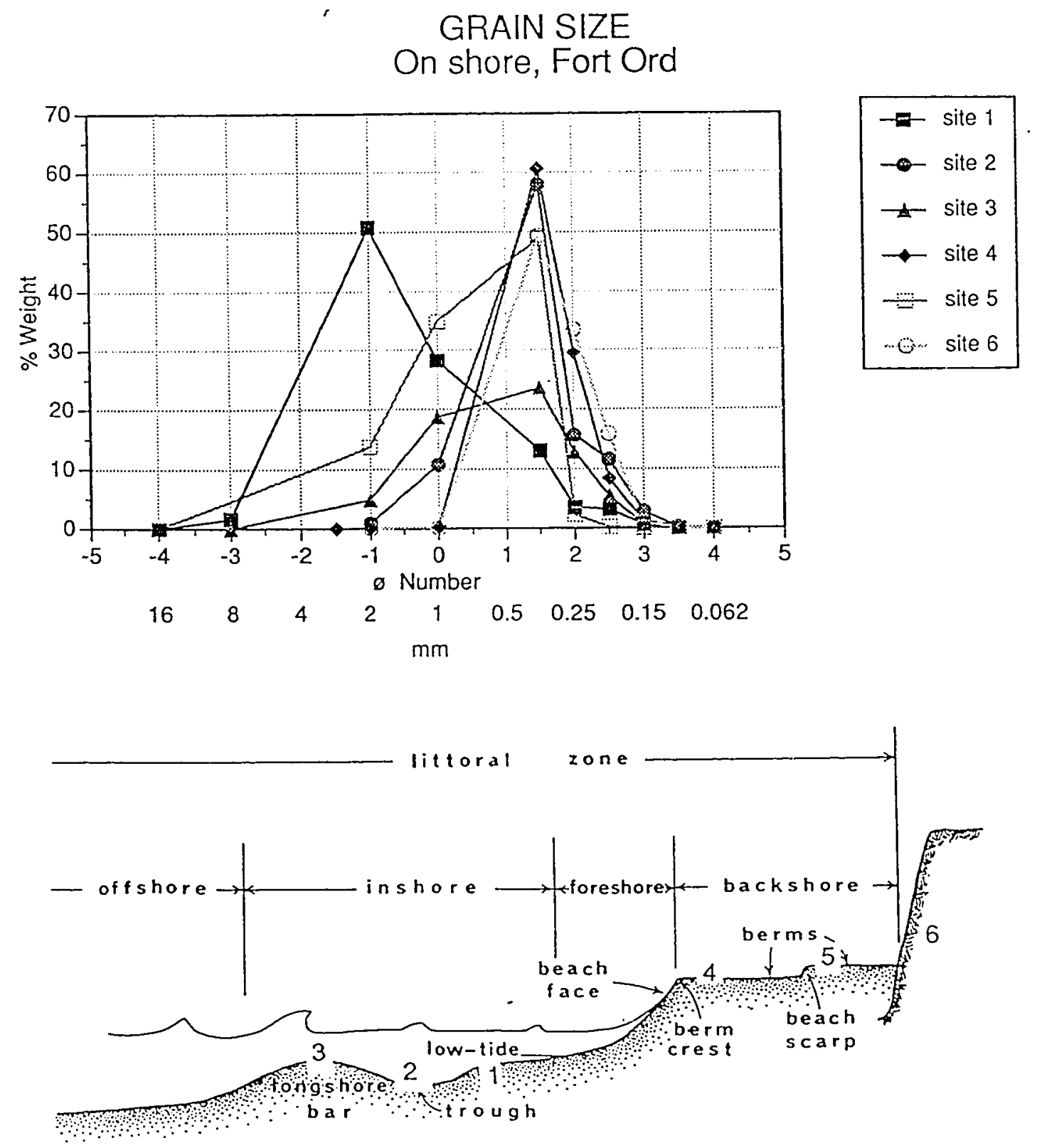

Figure 5. Grain size on the beach and in the near shore zone on Fort ord near stillwell Hall. The numbers on the beach profile refer to the site locations on the graph above. (Beach profile after Komar, 1976) 


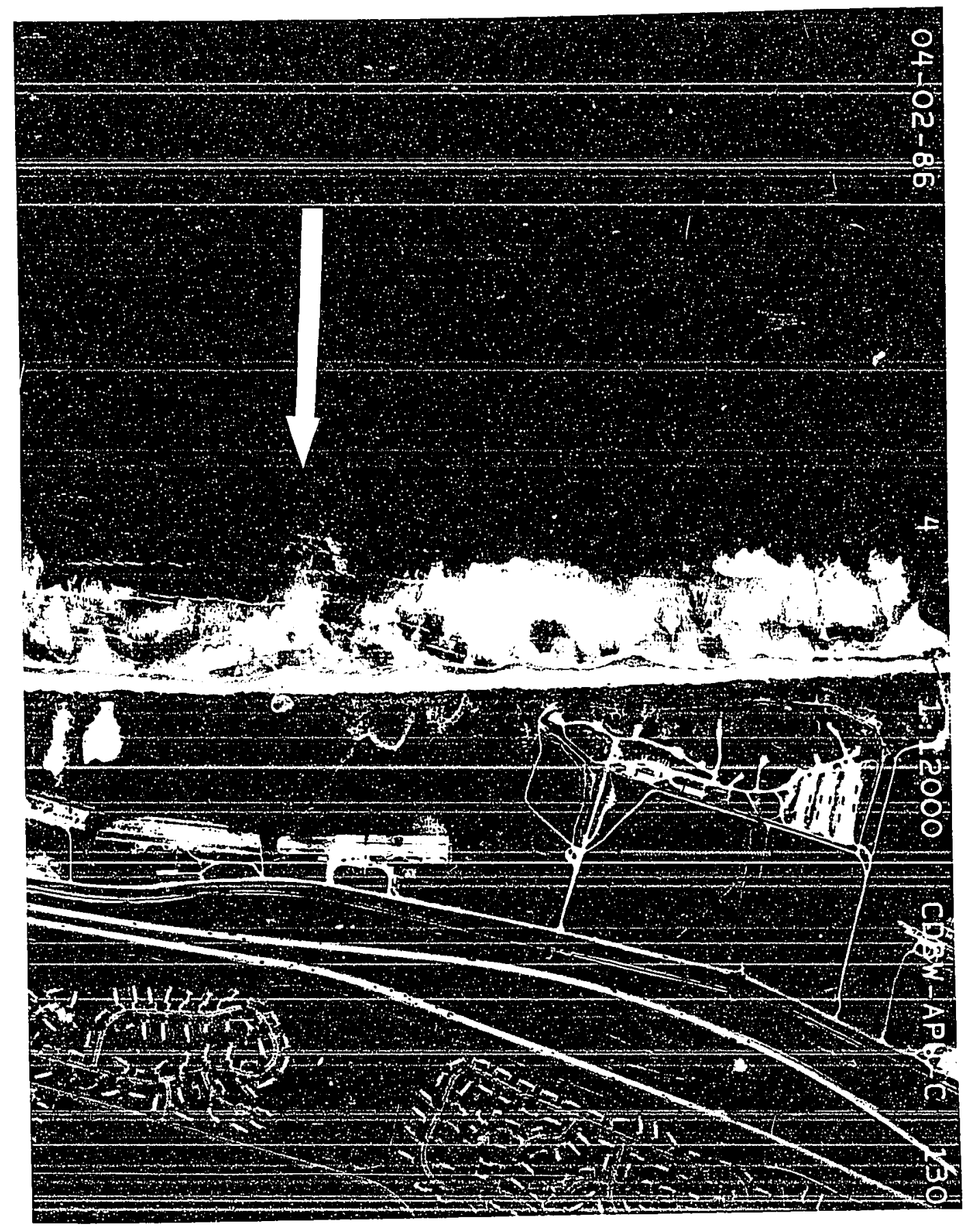

Figure 6. Aerial photograph of study area arrows point to a rip cell and plume of sediment entrained in a rip current. 
of the California Undercurrent.

Waves and Tides

Swell is the most significant source of wave energy in Monterey Bay (Smith, 1993) and is characterized by both Pacific Ocean swell (wave periods of $8 \mathrm{sec}$ and greater) and locally generated wind waves. Early spring and summer are characterized by swell from the southwest, while in the fall and winter, swell is from the west and northwest (Fig. 7). The rocky headlands at Point Pinos and Point Santa Cruz and combined with the Monterey Submarine Canyon, act to bend the wave-front into a shape similar to that of the shoreline (Sklavidis et al., 1985)

The distribution of sediments in Monterey Bay and the shoreline shape are, in a large part, a response to wave conditions. Sediments found near the shore, where waves affect the bottom, tend to be coarser than those found offshore (Smith, 1983). Storms from the west to northwest, during the winter have the greatest impact resulting in high waves along the Fort ord coastline in Monterey Bay (Smith, 1983; Thornton, 1985).

Tides in Monterey Bay exhibit the diurnal inequality typical of most of the west coast of North America. The Monterey Canyon moderates both tidal ranges and tidal influence on coastal currents. Data from the National Oceanic Atmospheric Administration (NOAA) indicite that the tidal 
A.

B.
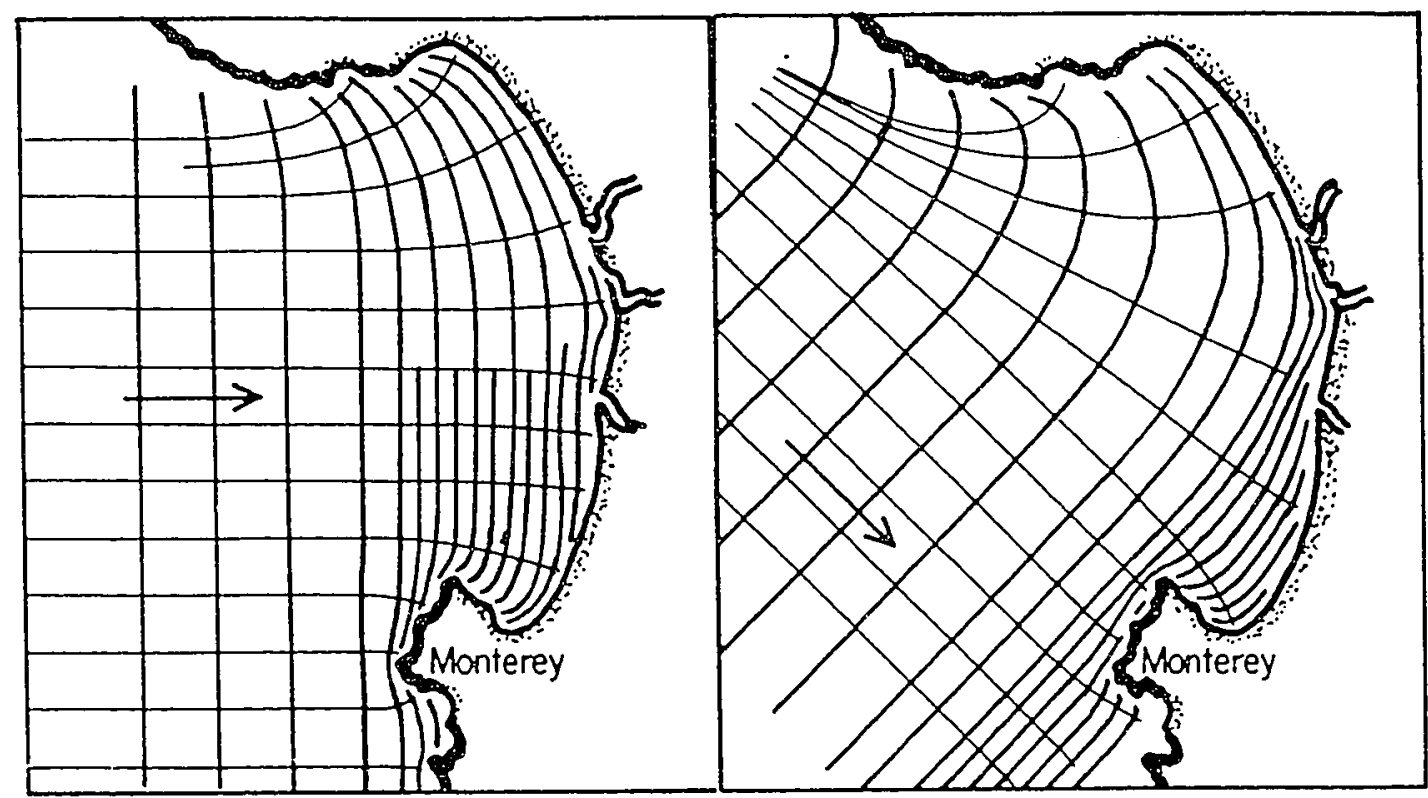

$T=12$ sec., direction: $W$

$\mathrm{T}=12 \mathrm{sec}$, direction: $\mathrm{NW}$

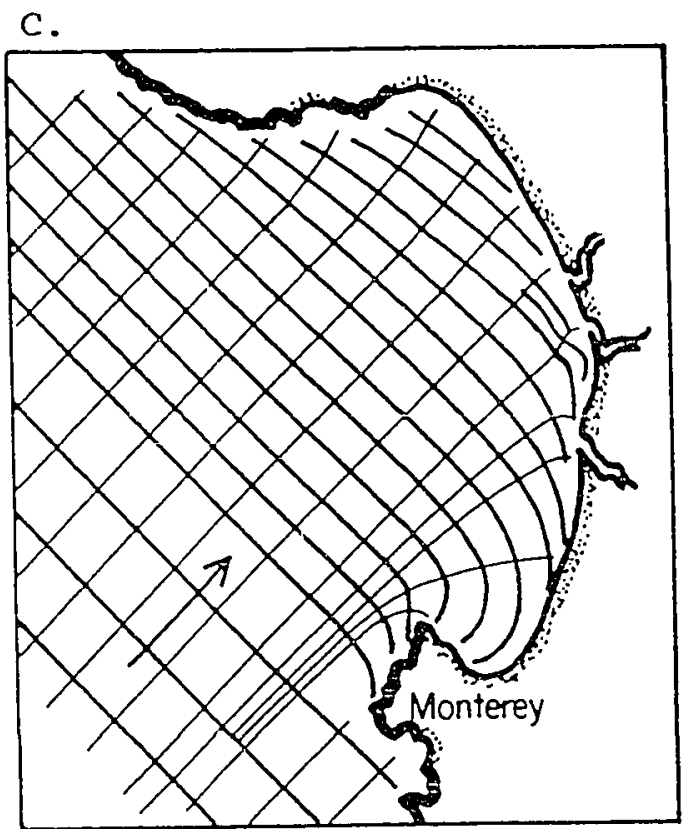

$T=12$ sec, direction: $S W$

Figure 7. Seasonal directions of wave approach and wave refraction patterns in Monterey Bay. Fall and winter swell is from the west and norththwest $(A \& B)$ While Early spring and summer swell if from the southwest (C) (After Weigle, 1965) 
current is too weak and variable to be predicted, and seldom exceeds $0.1 \mathrm{knot}(25 \mathrm{~cm} / \mathrm{sec})$. The tidal parameters for the southern Monterey Bay are a mean range of $1.07 \mathrm{~m}$, diurnal range $1.62 \mathrm{~m}$, and mean tidal level $0.85 \mathrm{mmllw}$ (NOAA, 1983). Near Shore Circulation

Near shore circulation of ocean water responds to wave activity that occurs during the three seasonal directions of wave approach (Fig. 7). Longshore currents result from waves striking the shore at an angle to the near shore bottom configuration. Welday (1972) found that during the late fall, winter and early spring the prevailing wave crests in southern Monterey Bay are $\mathrm{N} 10^{\circ} \mathrm{E}$ to $\mathrm{N} 20^{\circ} \mathrm{E}$, with their orthogonals averaging about $\mathrm{N} 75^{\circ} \mathrm{W}$ (WNW). With waves from this direction, southward littoral migration occurs from the mouth of the Salinas River to Sand City. From that point southward to seaside the wave fronts are parallel to the shoreline, and therefore significant littoral transport is not likely. From Point Pinos to Seaside littoral drift dominates and ultimately turns offshore.

Dorman (1968) found a series of rip current cells and a southward flowing longshore current caused by wave action along the eastern bay shore (Fig. 8). This current does not continue along the coast, but turns seaward just south of sand City where it is met by a weak cyclonic gyre that predominates 


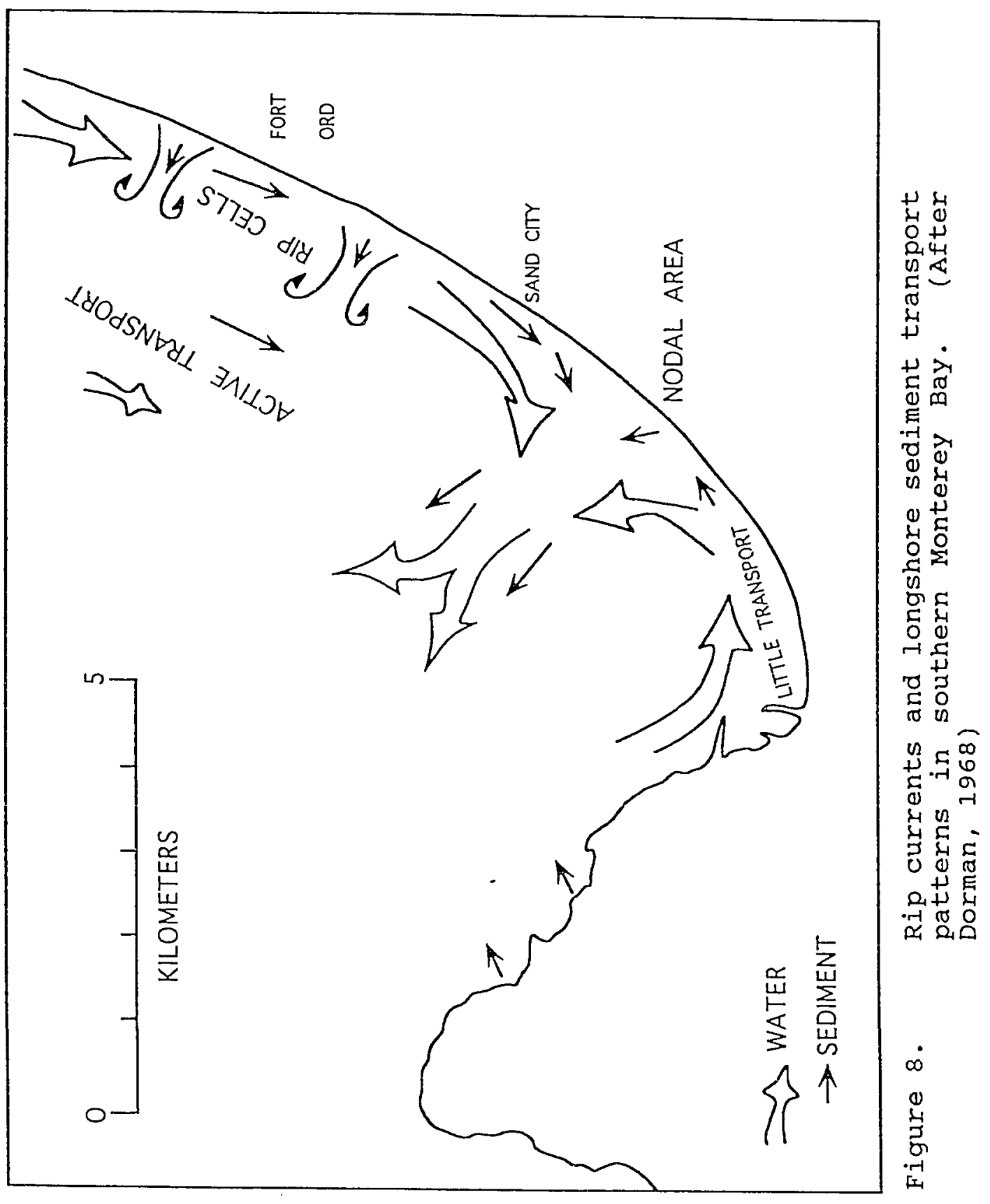


in the southern bay (Dorman, 1968).

Several studies have suggested that the southern portion of Monterey Bay comprises a nearly complete littoral cell with boundaries at the Monterey Canyon and at Point Pinos (Fig. 9) (Dorman (1968), Dittmer (1972), and Oradiwe (1986). Major sediment inputs include the Salinas River, erosion of dunes bordering the beaches, shoreline erosion and abrasion of the granodiorite exposed on the Monterey Peninsula. The entire cell is thought to be stable in shape and size, in spite of the high erosion rates (Table 1 ) in the area (Griggs and Jones, 1985).

Near Shore Sedimentary Processes

Inman (1957, 1963) investigated oscillatory ripples from the surf zone to a depth 50 meters along the sandy shelf bordering the coasts of southern California, Mexico, and the Hawaiian Islands. With supplementary information from laboratory measurements he found a relationship between ripple spacing and orbital diameter. As orbital diameter increases, ripple spacing increases until a maximum is reached and the ripples fade out and sediment transport is initiated (Fig. 10). Komar (1976) found that rip current cell circulation can redistribute beach sediments and have a profound effect on beach configuration and sediment transport. For example, troughs scoured by rip currents may act to stabilize the rip current position. The cell circulation is then strongly 


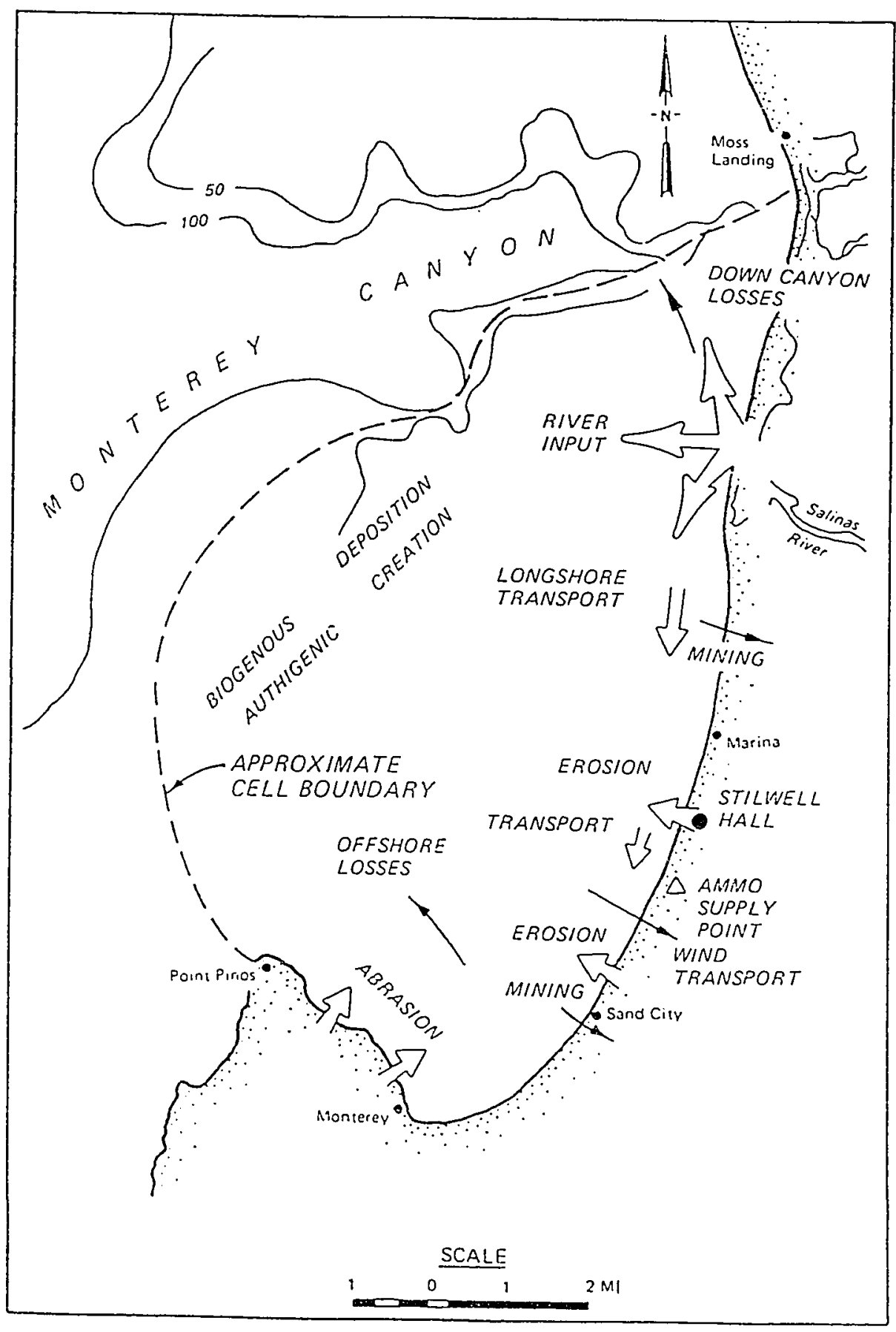

Figure 9.

Littoral cell boundaries and sediment sources and losses in southern Monterey Bay. (From Dorman, 1968) 

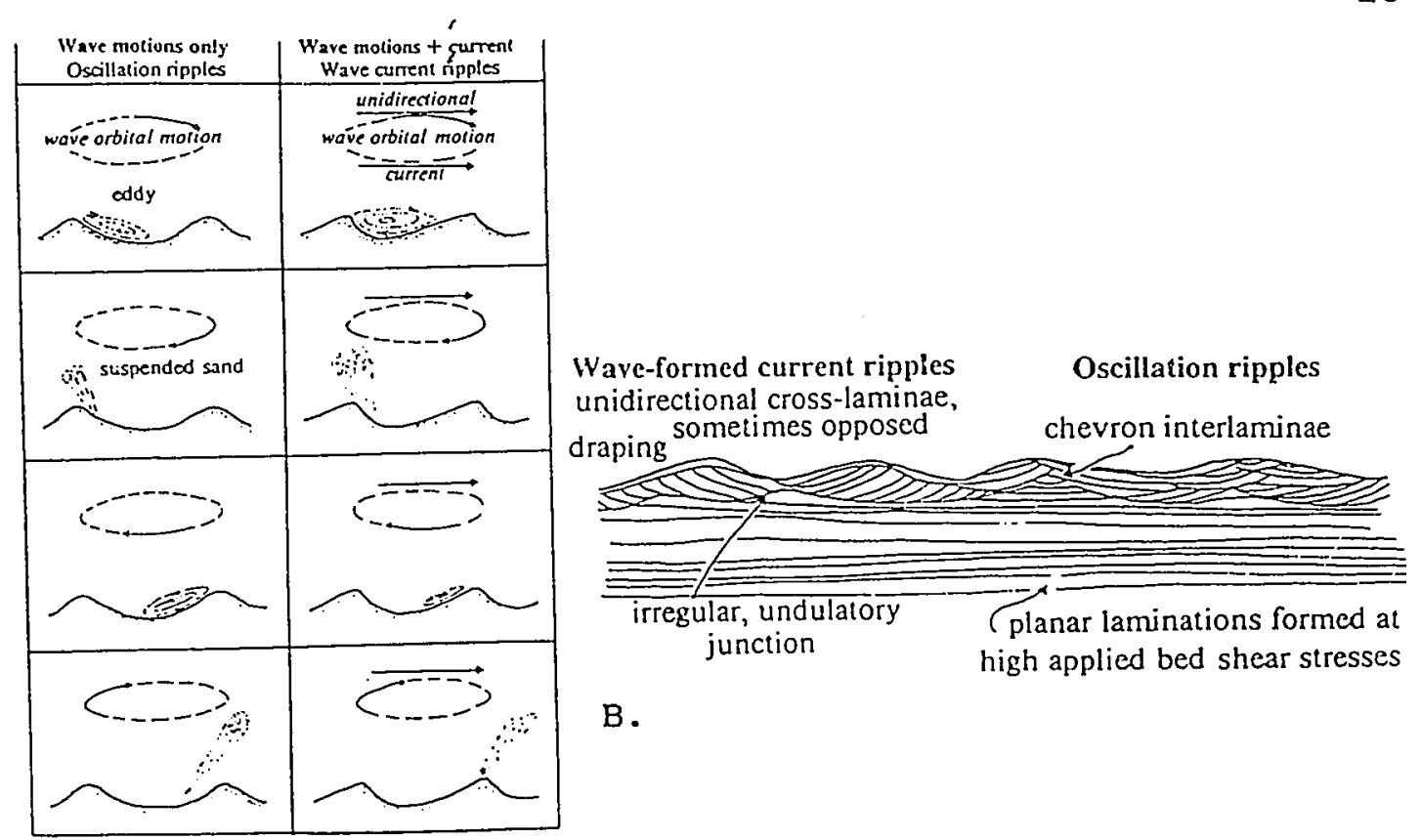

B.

A.
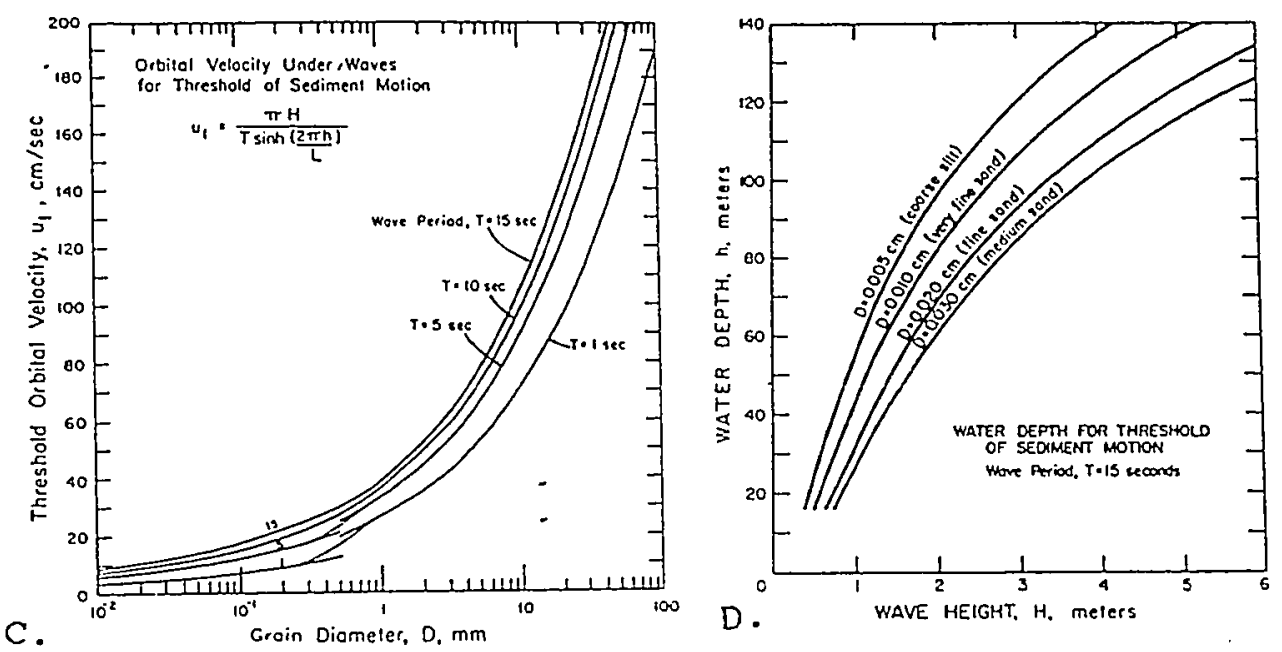

Figure 10.

Bedforms and structures formed by water waves. A. Relationship between sand motions in a rippled sea bed and the orbital motions of waves with and without a unidirectional current. (After Komar, 1976) B. Diagnostic internal features of wave-formed ripples (after de Raaf et al. 1977). C. Threshold orbital velocity required for motion of quartz grains, and D. the water depth and wave height required. (From Komar and Miller, 1975) 
affected by the beach topography and is not completely free to respond to changing conditions of swell waves and edge waves. The seaward flow of a rip current occurs where the waves and the set-up is lowest and the longshore currents converge (Fig. 11). The cell circulation therefore depends on the existence of variations in the wave height along the shore.

In a wave basin, swell waves may generate standing edge waves on the beach that have the same period as incoming waves. Edge waves are standing waves with crests normal to the shoreline. Edge waves are best observed as a series of tongues of swash that run up on the beach face and the wave height is greatest at the shore and decreases rapidly offshore and fading out past the breakers. The interaction of the incoming swell and edge wave produces high and low sections of the incoming breakers and forms a regular pattern of circulation cells with evenly spaced rip currents (Fig. 11). A significant factor can be the interactions between the edge wave and the incoming swell is the generation of cell circulation. The large and small breakers remain at fixed antinode positions, every other antinode is the site small breakers. Since the rip currents occur at every other antinode which is a site of small beakers, a regular pattern of rip currents and cell circulation is produced.

Niedoroda et al. (1984) have shown that during non-storm conditions there is a tendency for sand to be moved only on 


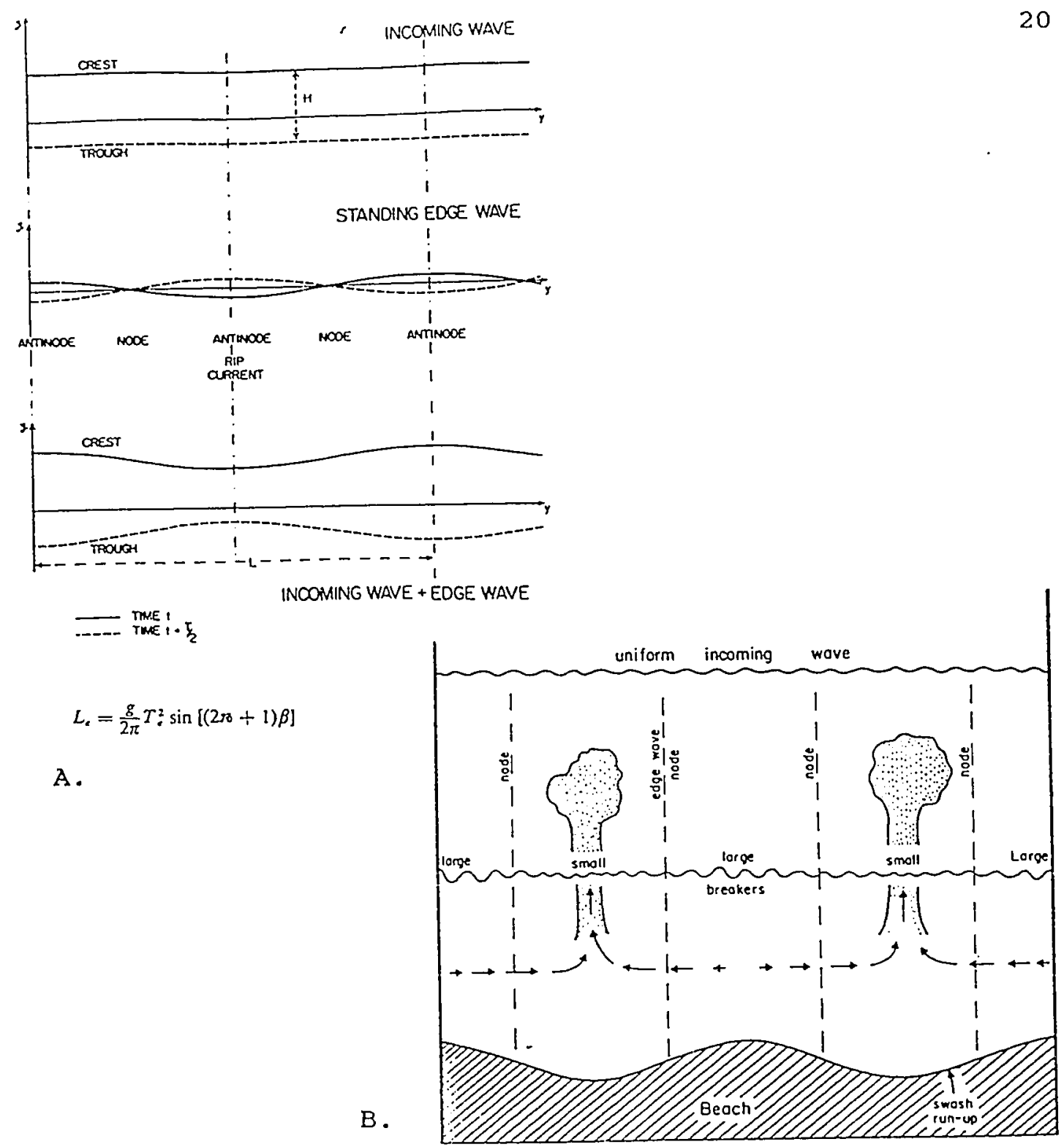

Figure 11. Rip cell morphology. A. Addition of the incoming swell and the standing edge wave at the breaker position give a longshore variation in the observed breaker height. The net height is greatest where the incoming wave are in phase and lowest where they are $180^{\circ}$ out of phase. B. The positioning of the rip currents is where the breaker height is smallest that is were the edge waves and the incoming wave are $180^{\circ}$ out of phase. (from Komar, 1976) 
the upper shoreface by asymmetrical near bottom wave orbital velocities. During storms the larger waves increase nearbottom orbital velocities that entrain sand over the entire shoreface. Sand is then transported both parallel and normal to the shore. Transport extends across the shoreface onto the inner continental shelf. In an erosional regime where sea level is rising sufficiently with respect to the rate of sediment input, Niedoroda et al. (1984) suggest that storm induced downwelling currents move sand seaward faster than wave orbital currents can return it. The primary sediment source is the shoreface and storms can strip away the entire beach prism and back-barrier. Presumably the inner continental shelf an important sink for the material eroded from the shoreface.

Rippled zones parallel to the shore and shore-normal bands of coarse sand have been observed on sonographs of the inner continental shelf of southern Monterey Bay (Hunter et al., 1988), between Bodega Bay and Point Arena (Cacchione et al., 1984) and along the moderate to high energy Pacific coast of Mexico (Reimnitz et al., 1976). Hunter et al. (1988) studied rippled zones and bands of coarse sediment at water depths between 10-30 meters that are approximately 20-100 meters wide, and $1 \mathrm{~km}$ from shore. These workers observed changes in the length, width and locations of the coarse sediment bands and zones by comparing series of side-scan 
sonar surveys. They proposed three modes of offshore transport: 1) seaward-flowing rip currents, 2) seaward flowing bottom currents that are generated in part by storm winds, and 3) other currents including Langmuir currents that are generated in part by wave and wind action. Cacchione et al. (1984) described rippled scour depressions on the inner continental shelf off central California that are similar to those observed in southern Monterey Bay. They found elongate depressions normal or slightly oblique to the general trend of the isobaths and containing large, long crested ripples, and smooth areas of no perceptible relief on side scan records, but covered with well defined oscillatory ripples (wavelengths of $20-30 \mathrm{~cm}$; heights of 2-5 cm) distributed along the coastline between Bodega Bay and point Arena. Current and wave data taken seaward of Bodega Bay and Point Arena during storms suggest that nonuniform downwelling-induced currents and large waves are the cause of these features. Southern winds that could produce downwelling are common along the central California Coast during late fall and winter storms. They concluded that the ripples are wave-formed based upon existing models relating ripple geometry to wave conditions.

Side-scan sonar records of Reimnitz et al. (1976) taken along the high-energy Pacific coast of Mexico show ripplemarked bands normal to the surfline. These bands were traced 
as far seaward as $1.5 \mathrm{~km}$ to depths of $30 \mathrm{~m}$. The ripple marked bands were observed only near the coast and not on survey tracks seaward of the $30 \mathrm{~m}$ contour. Areas with ripple zonation generally correspond to areas where pronounced ripcurrent heads were crossed or seen a short distance shoreward. Reimnitz et al. (1976) suggested that this correspondence is indicative of ripple bands produced by rip currents. They also suggest that rip currents that develop under severe wave conditions transport sediment, modify the seafloor, and produce internal sedimentary structures much farther seaward than was previously believed.

\section{METHODS}

This study was designed to determine the origin of the sediment ripple bands and zones in the southern Monterey Bay. Sediment transport processes were evaluated and the role of seasonal or storm induced migration of these rippled beds was investigated. Side-scan sonar, cores and aerial photo studies documented changes in the nearshore morphology, changes in the location and scale of rip currents, changes in the size, shape and location of the rippled beds, as well as sediment grain size and lithology that compose the ripples.

Side-Scan Sonar

Side-scan sonographs were collected along ship's tracks on December 16, 1991, February 24, 1992, April 27, 1992 and 
June 22, 1992 aboard the R/V Ricketts (Fig. 12, Appendix I). Navigation was provided by a North star 800 Loran-C system. The navigational system is pre-set to an established latitude and longitude bias from the U.S. Navy G.P.S. receiver. This system gives a repeatable accuracy variation of $4.5-5.0 \mathrm{~m}$. Even with this equipment it was difficult to stay on course due to wind, waves, visibility and equipment failure. Depth was recorded on a $200 \mathrm{Khz}$ Lowrance model X16. Side-scan sonographs were collected on a Klein Digital Sonar system 590. The system produces a "plan view" photo-like image of sea floor acoustic scattering. Transducers mounted on both sides of the $1.02 \mathrm{~m}$ long towfish emit a $100 \mathrm{KHz}$ frequency acoustic signal. Differing intensities of the acoustic scatter signal produce images of the sea floor similar to those produced by aerial photography, although the source of backscatter is complicated. The backsides of positive topographic features are marked by an acoustic shadow or light regions on the records that are caused by blockage of the acoustic scatter. outcrops of bedrock and sand ripples produce dark images, as a result of high acoustic backscatter, whereas depressions, fine-grained sands, and muds produce lighter images, indicative of less backscatter. A swath width of 200 meters (100 meters per side) was used and survey lines were laid out to provide a minimum of 20 meters (10\%) of overlap between lines. Records from all cruises were used to construct three 
maps to show changes in the configuration of the sand waves. Cores

Gravity coring was tried but due to the sandy nature of the substrate proved to be ineffective. The corer bounced off the coarse grained rippled beds and landed on its side.

Diver-operated push-down box corers and a pound-down corer on loan from the U.S. Geological Survey, were used on June 22,1992 . Cores were taken from the center and adjacent to the rippled bedforms. Cores from the pound-down corer were used to determine surface stratigraphy of the beds, while samples from the box cores were used for grain size analysis. The divers also measured the ripple height and wavelength for comparison to measurements from the sonographs. Two $0.5 \mathrm{~m}$ cores and one $0.30 \mathrm{~m}$ box core was taken in the rippled site and one $0.5 \mathrm{~m}$ core and one $0.30 \mathrm{~m}$ box core was taken adjacent to the site.

Aerial Photographs

Aerial photographs of the southern Monterey Bay shoreline were studied at the University of California at Santa Cruz map library. This study was done to determine: 1) if the rhythmic topography, consisting of longshore bars separated by rip currents migrates in the longshore direction seasonally, 2) do the rippled zones found offshore migrate as well, and 3) does the spacing of longshore bars remain constant and is it similar to the spacing of the shore-normal zones. 
Wind and Wave Data

wind and wave data used in this study were gathered from the Coastal Data Informational Program Monthly Reports, a cooperative program of the U.S. Army Corps of Engineers and California Department of Boating and Waterways. Data were recorded at measuring stations in the Marina array. This information was used to determine if waves can produce the threshold velocity needed to transport sediment in the study area.

\section{DATA PRESENTATION}

Maps

The location maps of the rippled bands and zones (Fig. 12), prepared from the images on the side-scan sonographs, revealed temporal changes in the geometry of these features. on the sonographs the rippled bands and zones are darker than the surrounding fine sand, have a visibly rippled pattern and are sharply bounded. Depth records and shadow effects on the sonographs indicate the depressions are smooth except for the ripples and are up to $1 \mathrm{~m}$ lower than the surrounding area with steep sides. A chart (Fig. 13) was prepared to examine the variations of ripple spacing with time and distance from shoreline.

Cruise I

Sand waves are clearly delineated (Fig. 14) on the sonar records taken on December 16, 1991. Large shore-normal zones 


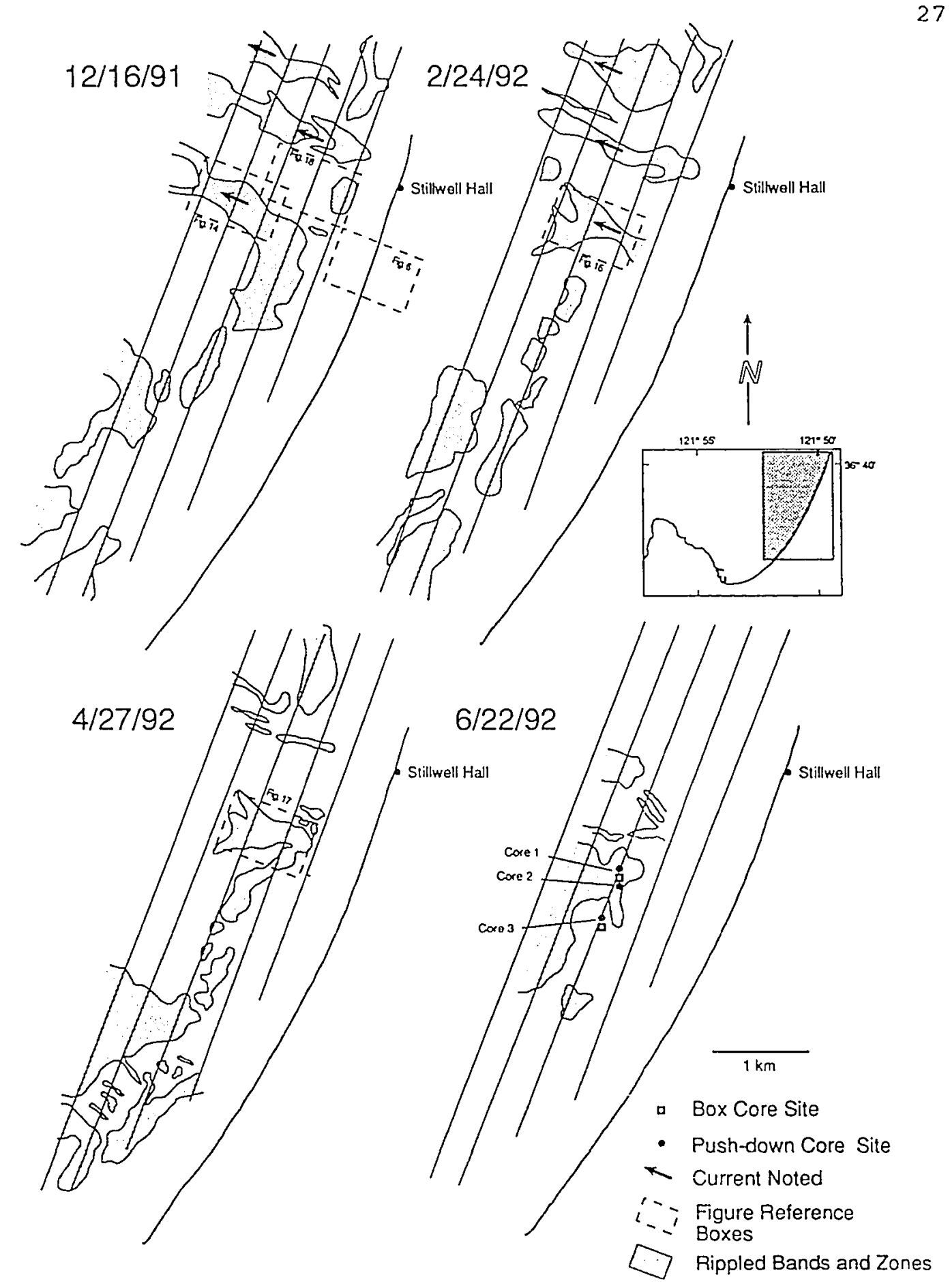

Figure 12. Maps showing the December through June changes in the shape and size of the bands and zones of rippled coarse grained sediments in southern Monterey Bay. 
Ripple Wavelengths Off Fort Ord

December 16, 1991, February 24, 1992, April, 27, 1992
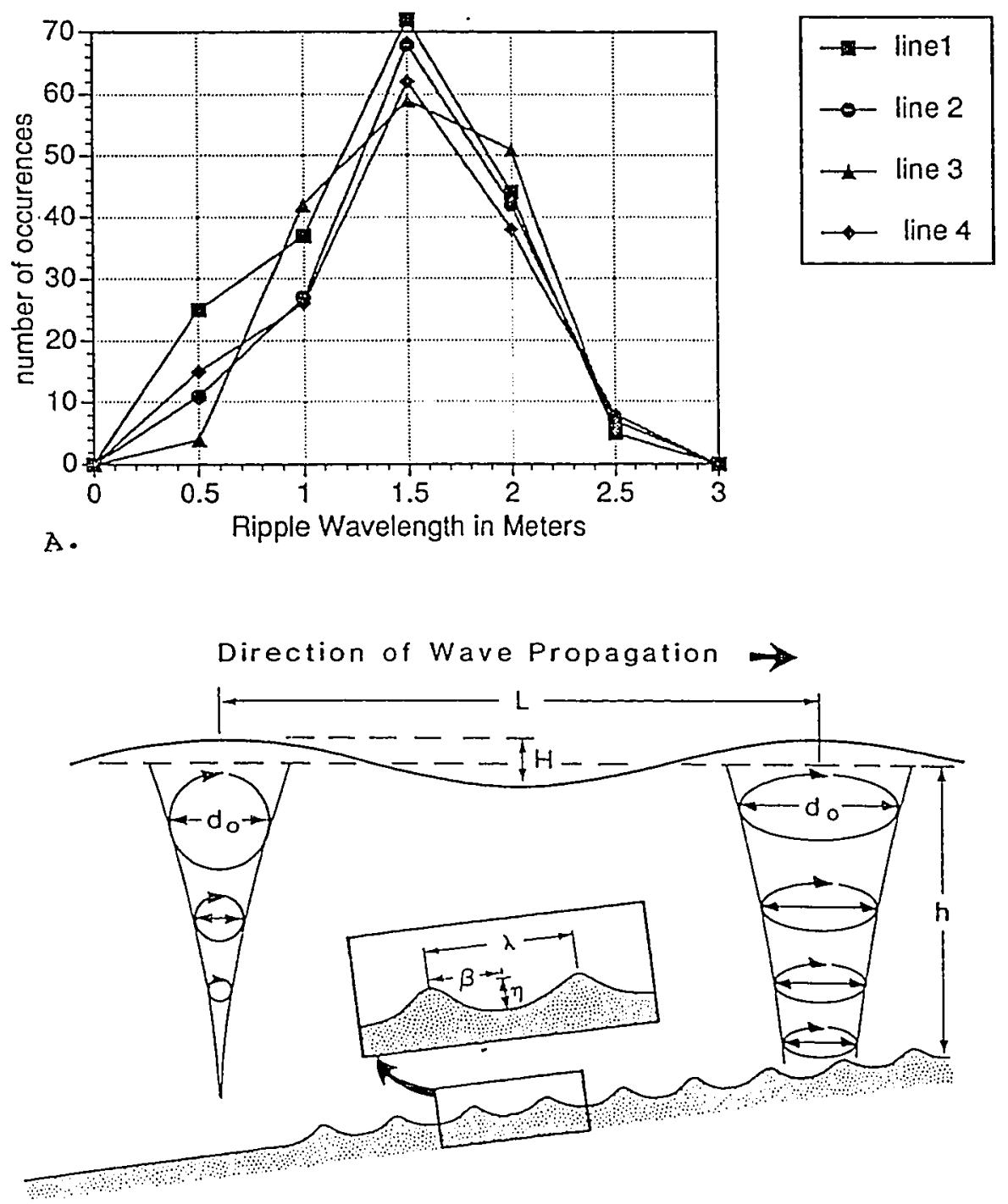

B.

Figure 13. A. Ripple wavelength diagram showing the difference in the spacing on different
navigation Iines. Line 1 is closest to the shore and line 4 is the farthest off shore. $B$. Schematic diagram of the wave orbital velocity, the orbital diameter near the bottom, and the generated oscillatory ripple marks (After Clifton and Dingler 1984). 

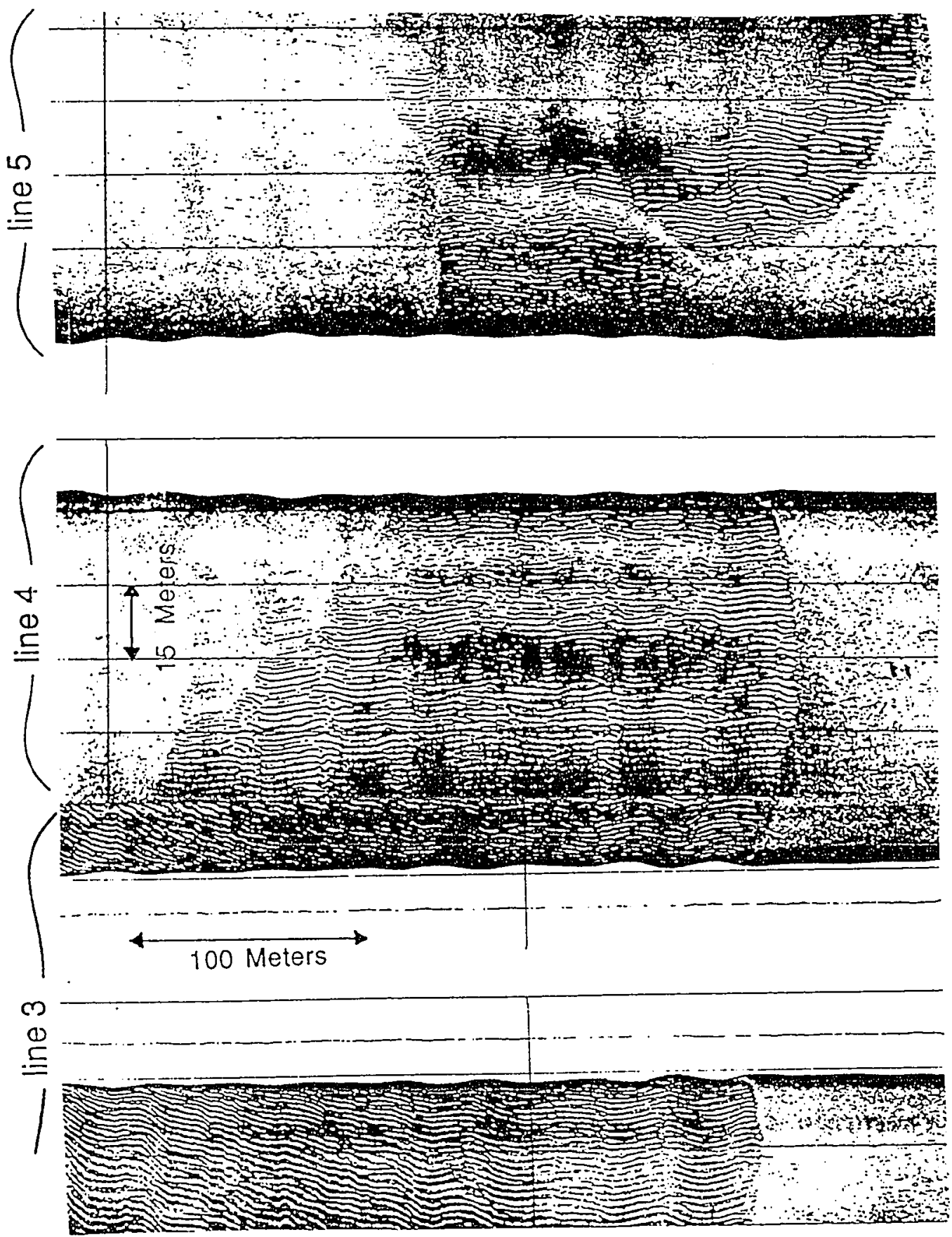

Figure 14. Mosaic of sonograms taken on Cruise I, December 16, 1991. The location, orientation and navigation line is shown on Fig. 12 . 
of sand waves were located in the northern and central portions of the study area (Fig. 12). The significant wave height was $1.2 \mathrm{~m}$ with a period range of $12-16$ seconds (Appendix II). The significant wave height for the previous seven days ranged from 1.1 to $2.3 \mathrm{~m}$ with an average of $1.7 \mathrm{~m}$; periods ranged between 10-16 seconds. The seas were calm and there was no wind, this facilitated the detection of currents normal to the shoreline at various locations (Fig. 12). At these sites the velocity of the $R / V$ Ricketts changed from 2.93.2 knots to $2.6-2.8$ knots and it was necessary to alter the course by $10^{\circ}$ to $15^{\circ}$ to correct for sideways drift. Using the law of cosines, surface current speeds were estimated between 1-2 knots $(0.70-1.00 \mathrm{~m} / \mathrm{sec}, 70-100 \mathrm{~cm} / \mathrm{sec}$.$) based on the$ deflection of the ship's course. These currents appear to exceed the threshold velocity needed to initiate sediment motion at depths up to $30 \mathrm{~m}$ (Fig. 15) for grain sizes up to 10 $\mathrm{mm}$.

Cruise II

The sonar records taken on February 2, 1992 are not as clear (Fig. 16) which is probably due the high sea state. The towfish may have suffered from yaw and pitch, thus degrading the sonograph. The most dominant features were, however, mapped (Fig. 12). The shoreward portions of the sonographs along navigation line 1 exhibit diffuse high backscatter areas 


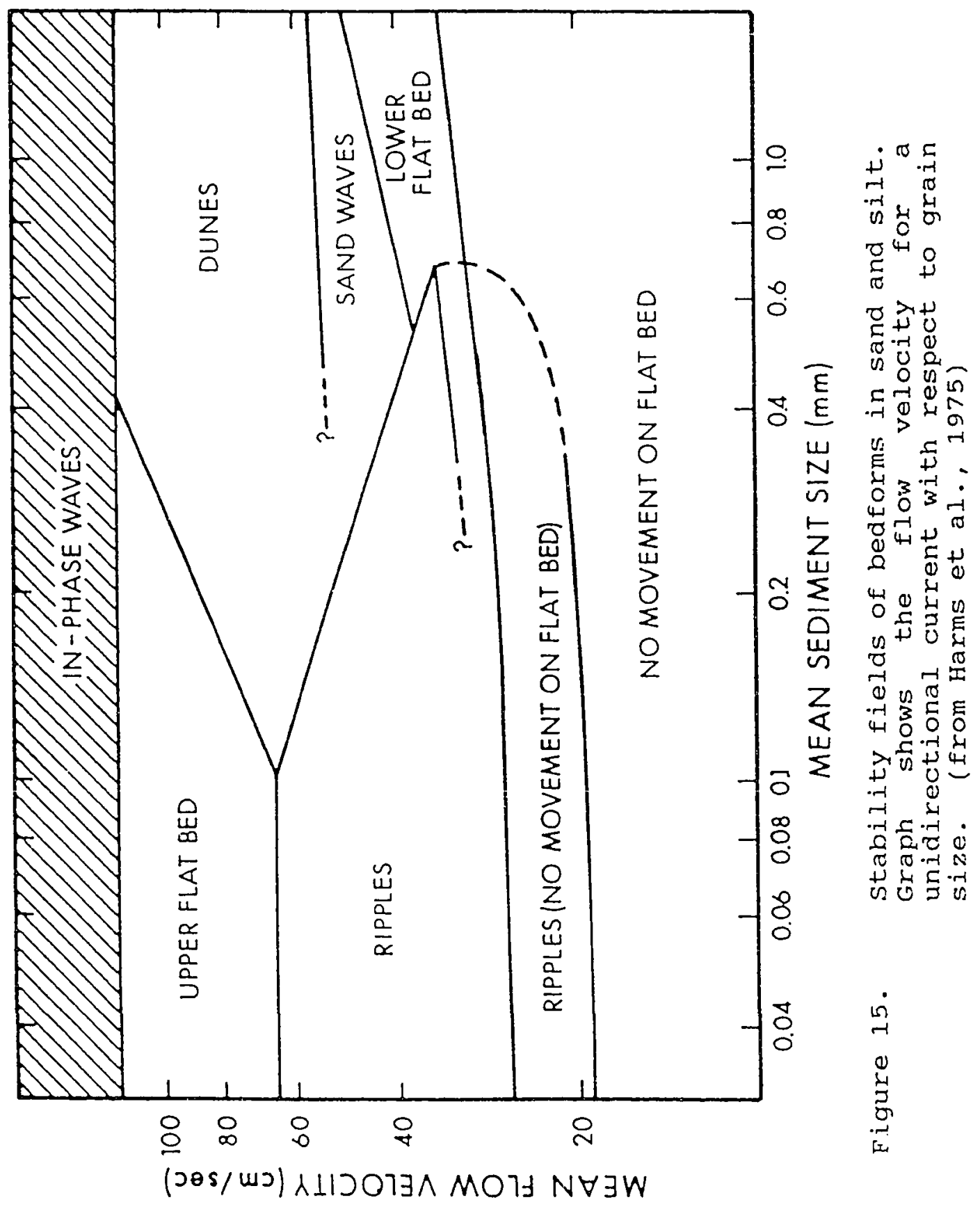



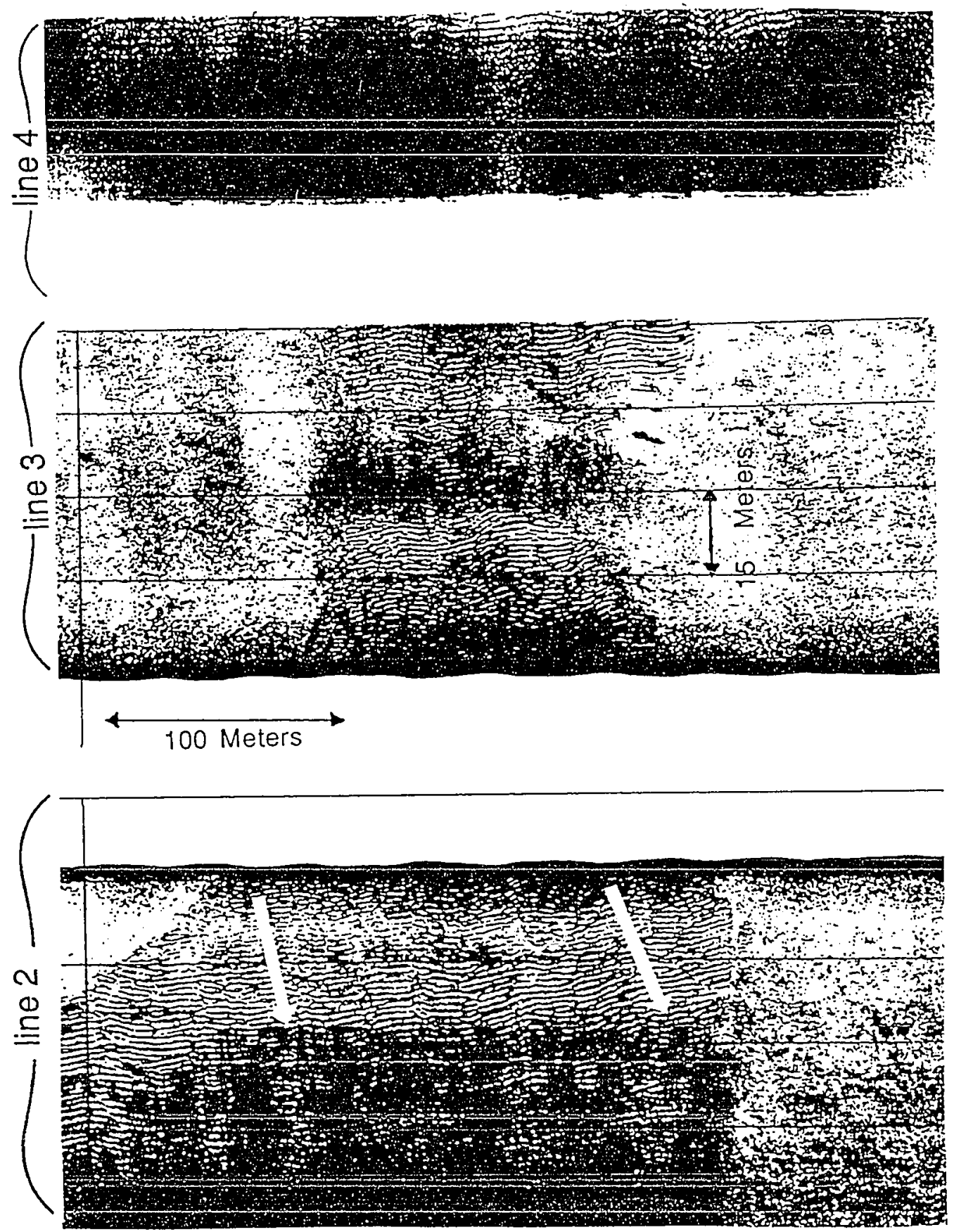

Figure 16.

Mosaic of sonograms taken on cruise II,
February 2, 1992 . White arrows point to a
possible cloud of suspended sediment. The
location, orientation and navigation line is
shown on Fig. 12 .


that has been inferred as clouds of suspended sediment by Hunter et al. (1988). On navigation line 4 (Fig. 12) high acoustic backscatter that may be rocks were noted $1 \mathrm{~km}$ offshore from stillwell Hall. The maximum daily significant wave height was $3.0 \mathrm{~m}$ with a period range of $10-12$ seconds (Appendix II). It was difficult to stay on course due to swell height and the $R / V$ Ricketts was pushed offshore at various sites (Fig. 12) by apparent off-shore currents. Velocity changes due to shore normal currents changed the boat speed from 3.1-3.3 knots to $2.6-3.1$ knots. Using the law of cosines or vector addition, surface current speeds of $1.0-2.0$ knots $(0.70-1.0 \mathrm{~m} / \mathrm{sec}, 70-100 \mathrm{~cm} / \mathrm{sec})$ were calculated for the offshore surface currents.

Cruise III

The sonar records taken on April 27, 1992 show rippled beds (Type A) grading into a second set of possibly older, pre-existing rippled beds (Type B), with gradational boundaries (Fig. 17). Only the clearest or dominant features were mapped. The significant wave height that day was $1.1 \mathrm{~m}$ with a period of 10-12 seconds, winds from the NW were strong and it was difficult to stay on course. There may have been offshore currents; however, due to the wind it was not possible to tell if the boat was pushed off course by wind or by a current. 

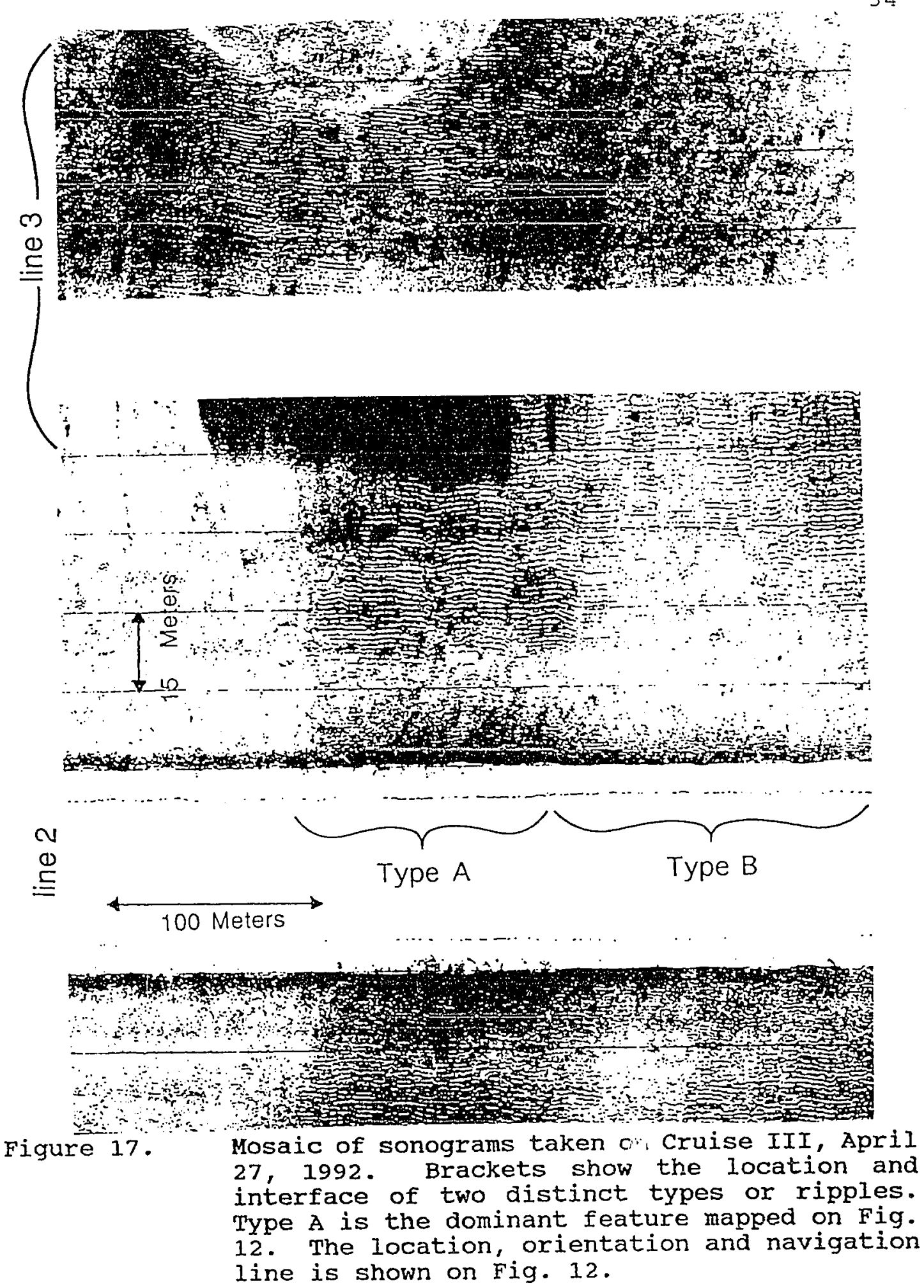


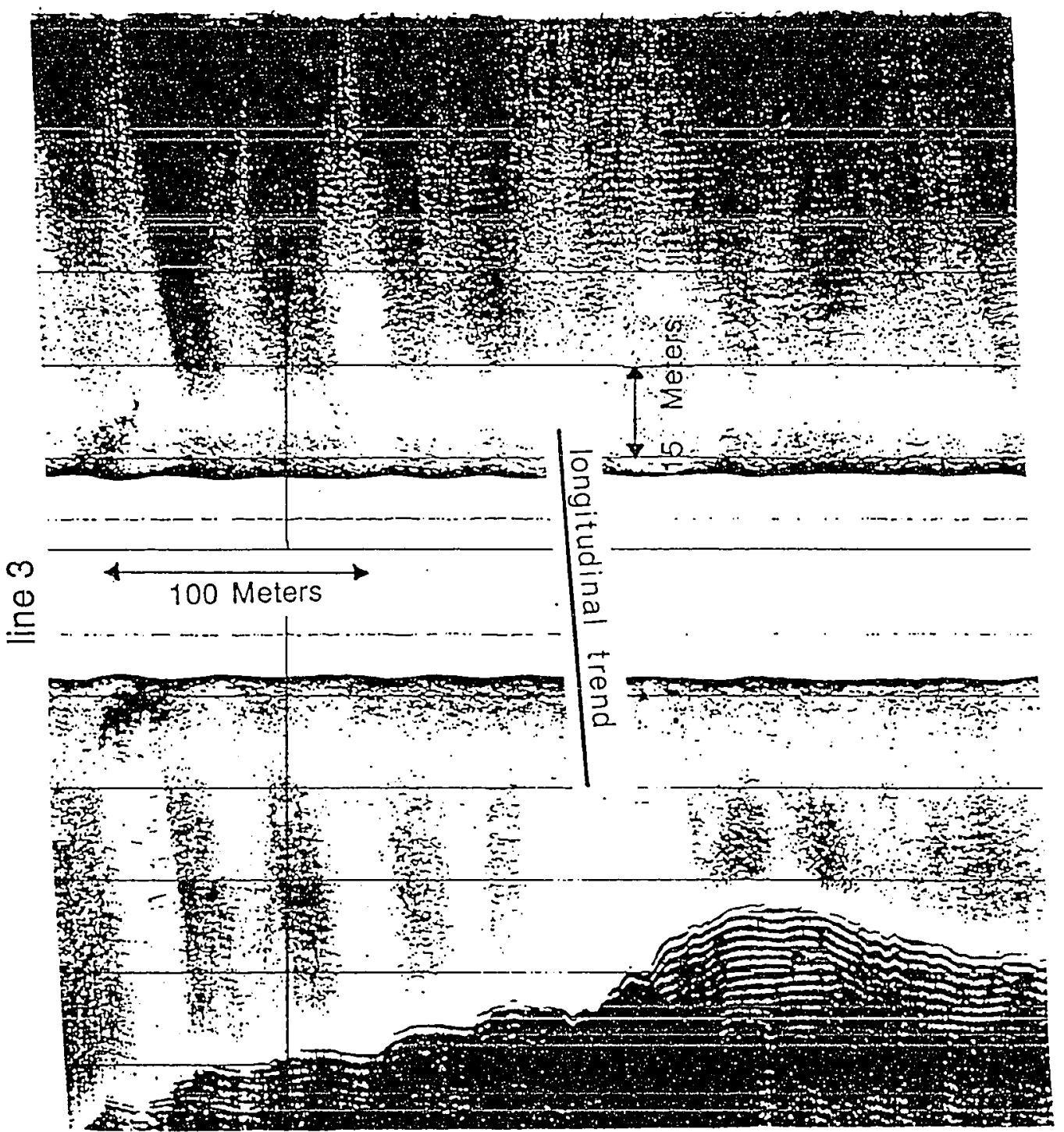

Figure 18 .

Mosaic of sonograms of longitudinal ridges taken on Cruise I, December 16, 1991. Sand or gravel waves with a wavelength of about 21 meters. The crests are mostly sinuous or herringbone pattern and extend at approximately right angles to the trend of the incoming train of waves. The abrupt boundary around the rippled band is caused by a shadow effect indicating that the ripples are in a scour depression that is $1 \mathrm{~m}$ lower than the surrounding area. The location, orientation and ravigation line is shown on Fig. 12. 
Longitudinal Ridges

Records from all three cruises display a series of ridges and troughs (Fig. 18) that are perpendicular to the shoreline. This longitudinal relief pattern becomes more widely spaced and less defined with increasing water depth. The wave lengths and heights of these features also varied on each cruise (Fig. 19), possibly as a result of changes in the wave regime (Komar, 1976). The ridges mapped on cruise I exhibited a maximum wavelength of $20 \mathrm{~m}$, whereas during Cruise II wavelength maximum was approximately $25 \mathrm{~m}$ and $15 \mathrm{~m}$ during cruise III.

Cores

Cores 1 and 2 (Fig. 20), which were collected from the shore parallel bands, penetrated through $0.25 \mathrm{~m}$ of coarse sand before entering bioturbated fine sand. The coarse grained fraction includes pebbles and shells. Most of the pebbles are of granitic composition similar to the granodiorite on Monterey Peninsula and all of the shells are lying with the concave side downward. Stratification varies from welldefined to nearly absent and bedding planes are flat to moderately inclined up to $20^{\circ}$. The median angle of crossbedding dips in two opposing directions, creating a chevron pattern similar to those shown in figure $10 \mathrm{~B}$, indicating an oscillatory flow (Komar, 1976; de Raaf et al., 1977; and 


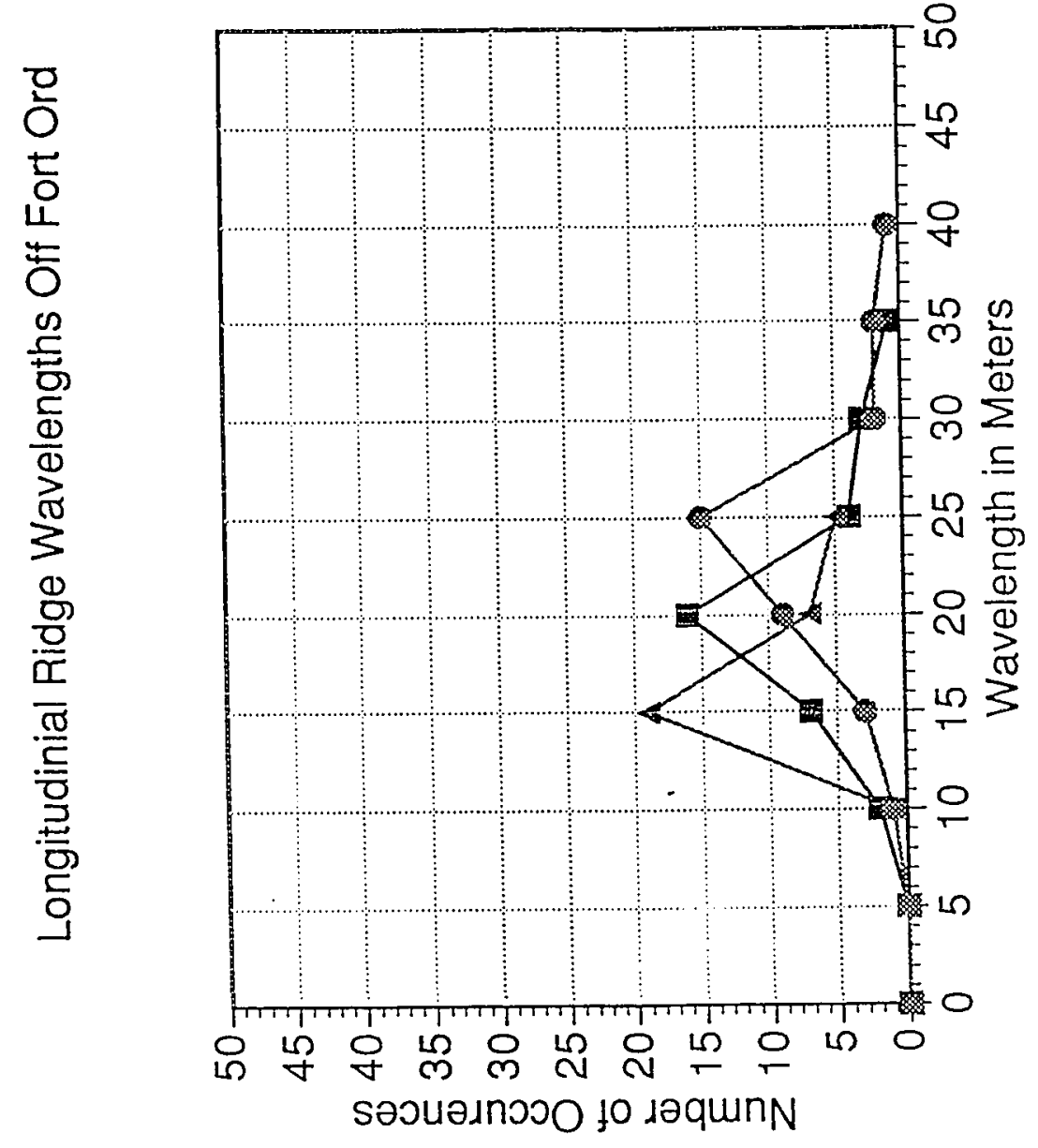

तु

न

नु त्न

\%

F.

ชั

E 9.

엉 भु

焉元兘

पै

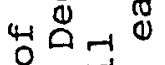

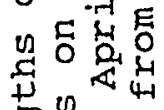

웜이

ธิ㇒

-1

ชण ऽ

3 क

ब运

मे ते $4 \mathrm{H}^{2} \mathrm{H}$ 04 궁

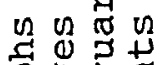
员乐

त。 0.

$4 .-10$

पैम कि

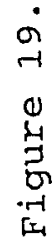


GRAIN SIZE

Off shore, Fort Ord

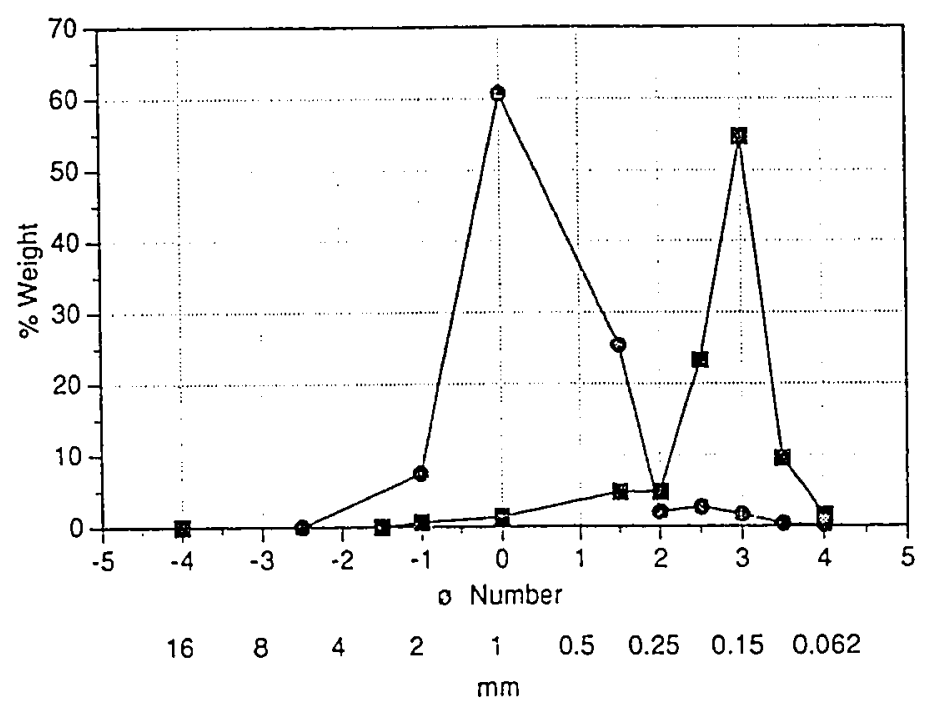

A.
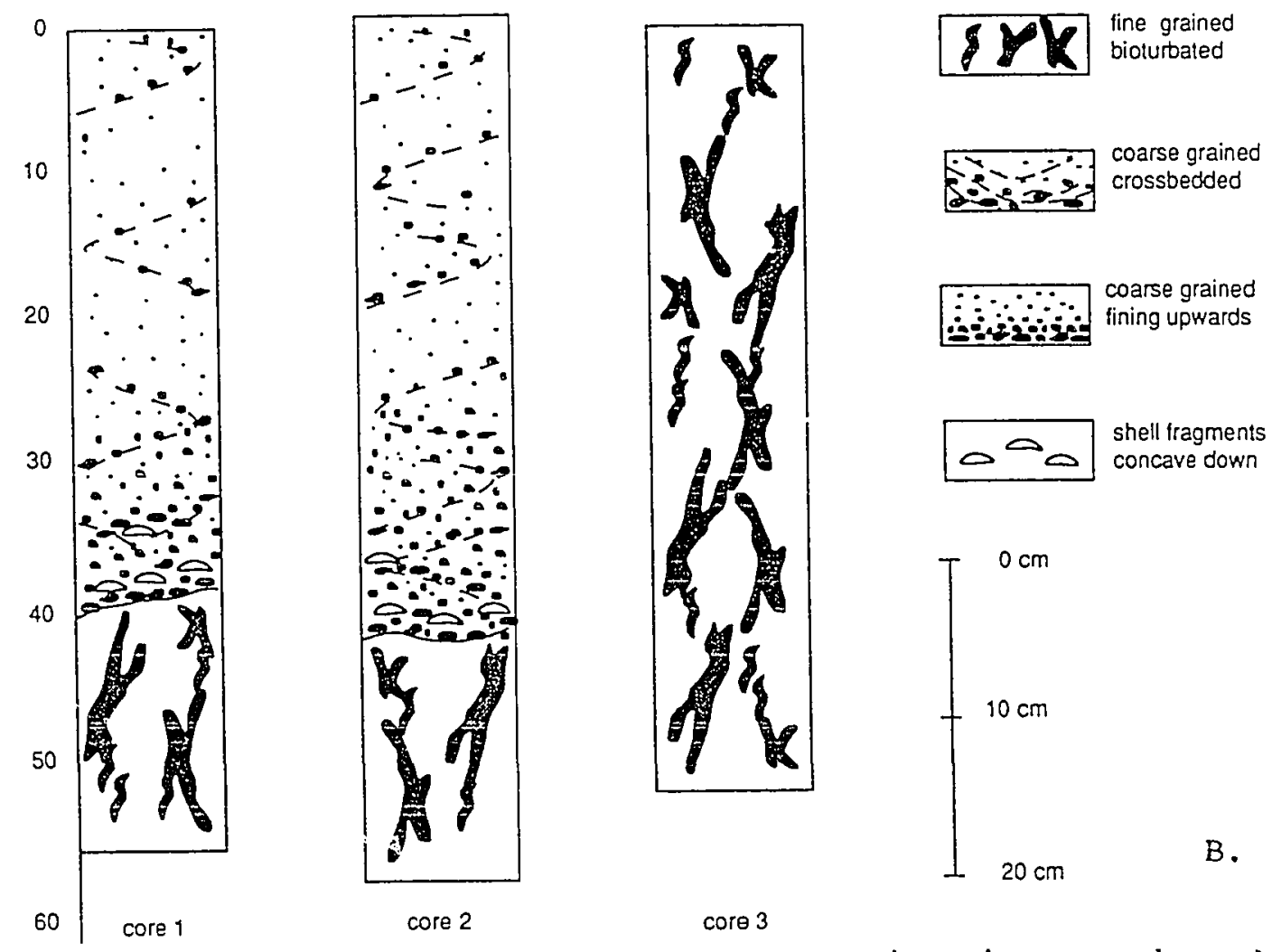

Figure 20.

Core stratigraphy and grain size graph. A. shows the results of grain size analysis on the sediment in the cores. $B$. shows the stratigraphy and Iithology of the cores. 
Clifton and Dingler, 1984)(Fig 10). The fine grained material below is highly bioturbated and is grayish brown grading down to mottled black to olive brown.

Core 3 collected adjacent to the rippled beds penetrated through the fine sand up to $0.50 \mathrm{~m}$ and did not contain coarse sand beds as found in cores 1 and 2 . This core consisted entirely of highly bioturbated fine-grained sand and silt that graded downwards from a sandy grayish brown to mottled black. sand and olive brown sand.

Aerial Photographs

Aerial photographs studied at the University of California at Santa Cruz Map Library show that the beach cusps, bars and trough spacing change in size, and at times, are absent. All of the aerial photographs indicate that the angle and direction of wave approach is such that the longshore current is from north to south.

Photographs taken on April 2, 1986 reveal predominant cusp and trough features that are largest near Marina and Fort ord, and decrease in size southward. Rip cell spacing ranged from 360-900 $\mathrm{m}$ and visible plumes of suspended sediment extended 420 to $920 \mathrm{~m}$ offshore (see Fig. 6 for an example). The spacing and visible plumes of suspended sediment are largest near stiliwell Hall on Fort ord. Although these photos are 5-6 years apart the locations of the troughs and rip-current generated plumes of suspended sediments are very 
close to the locations of the shore normal zones of rippled coarse sand located on the sonar mosaics taken on December 16 , 1992 (Fig. 12). The angle of wave crests with the shoreline is $20^{\circ}$ decreasing to $0^{\circ}$ to the south. Aerial photographs taken April 12, 1984 show similar patters of well defined cusp and trough morphology that is best developed near Marina and Fort ord, but then decreases in size southward. The cell spacing ranges from $240-780 \mathrm{~m}$ and plumes of suspended sediment extend 480-720 m offshore.

Photos taken May 6, 1978 and February 12, 1984 show the largest spacing and plumes near stillwell Hall and decreasing in size until they disappear in the south. The spacing of the rip cells ranged from $120-420 \mathrm{~m}$ and plumes of suspended sediment extended 180-360 m offshore. The angle of the wave crests with the shoreline is $10^{\circ}-15^{\circ}$ decreasing to $0^{\circ}$ to the south.

Photos taken October 5, 1976 and June 24, 1980 show no cusps, troughs, or plumes of suspended sediment extending offshore. The angle of the wave crests with the shore line is $10^{\circ}-15^{\circ}$ decreasing to $0^{\circ}$ to the south.

\section{DISCUSSION}

Erosion along the shore of Monterey Bay occurs when powerful winter storm waves, coupled with high tides, are able to rush up the foreshore and scour away at the base of 
unconsolidated sand dunes (MC Gee, 1986). The dune is undermined, causing its face to collapse and fall onto the berm. Successive waves entrain the sediment and carry it into the littoral transport zone.

The sizable erosion rates in the Southern Monterey Bay are due to the impact of high energy waves (Griggs and Jones, 1985). Although the orthognals diverge (Fig. 7) swell from the NW loses little energy from interaction on the bottom as it passes over Monterey Canyon.

This high energy wave impact has set up a series of large scale rip currents spaced up to $900 \mathrm{~m}$ apart and plumes of suspended sediment extending up to $920 \mathrm{~m}$ offshore. Cowell (1986) observed large-scale rip currents or "mega rips" on the inner continental shelf of Australia and suggests that this process is responsible for the seaward transfer of water and sediment across the shoreface and on to the inner continental shelf. The inner shelf floor becomes a major depocenter for sediments eroded from the shoreface. While the eroding shoreline is the primary source of sediment, a single storm can remove the entire beach, back shore berm and erode the dune face.

Rip currents and wind generated downwelling (Niedoroda et al., 1984), which become most active during storms, transport sediment from the littoral zone seaward. Water velocity, seaward distance, and spacing of these rip currents are 
directly proportional to wave energy and become well developed during high-wave events. Sites of large scale rip currents appear to be stationary for the season. Consequently the shore normal zones (Figs. 14, 16, 17) may provide important sites of offshore transport by the large scale rip currents.

At times of storm activity, wave action scours the bay floor sufficiently to form depressions as described by clifton et al. (1971). During these storms the intensified currents winnow the sediment and produce laterally extensive lag deposits consisting of shell fragments, pebbles and coarse sand in the depressions. The range in length, width and depth of these lag deposits is difficult to establish. They appear as large scale bed features in scoured depressions. They are from 1,000 to $1,500 \mathrm{~m}$ offshore, in an area 30 to $120 \mathrm{~m}$ wide. Most are beneath the outer portion of the zone of wave buildup, which is at a depth of approximately one-half of the deep water wavelength and the wave begins to interact with the bottom. The dominant bedform is a distinctive ripple that shows considerable variation in size and spacing (Fig. 14, 16, 17)

The large symmetrical ripples in the coarse sand zones and bands are wave ripples. The tendency for the ripple spacings to increase with decreasing depth (Fig. 13) suggests that the ripples are of the orbital type as described by Clifton and Dingler (1984), with spacing proportional to the 
orbital diameter of wave motion (Inman, 1957, 1963). The period and height of the waves that form the ripples were calculated using the method outlined by clifton and Dingler (1984), which is based upon Komar (1976). Using a ripple spacing of $0.8 \mathrm{~m}$, sediment grain size of $0.5 \mathrm{~mm}$, and water depth of $20 \mathrm{~m}$, the calculated wave period is $11.6 \mathrm{sec}$ and wave height is $1.4 \mathrm{~m}$. Wave periods of $10-12 \mathrm{sec}$ and wave heights of $2 \mathrm{~m}$ are common in the study area, suggesting that the ripples are not produced by storm conditions and that they are oscillatory wave ripples formed between storms.

The longitudinal ridges and troughs found on the sonograms (Fig. 18) are oriented parallel to the direction of rip currents. They appear as a series of ridges and troughs that produce a herringbone like pattern intermeshed with and bending the ripples in the bands and zones. These features may be a part of a rip cell circulation or edge waves. Komar (1976) states that if the incoming waves and edge waves have the same period, the large or small breakers remain at fixed antinode positions, with every other antinode position being the site of large breakers and the alternate antinode the position of small breakers. This theory could explain the location of the longitudinal ridges at the site of large breakers and the troughs at sites of small breakers.

Another possibility is that the longitudinal ridges form where longshore currents have the least interference with 
incoming waves, at the antinodal points. The longitudinal ridges may be sand waves formed by the longshore current. This could also lead to the conclusion that antinodes and standing edge waves may be partially driven by longshore currents.

The near shore cell circulation consisting of rip currents and longshore currents is normally generated by variations in the wave height along the beach (Komar, 1976; Bowen, 1969; Bowen and Inman, 1969). The water level shoreward of the higher breakers is raised above that of smaller waves, resulting in a net flow toward the position of small waves, where it converges and turns seaward as a rip current. This process is enhanced by wave refraction causing divergence and convergence of the wave rays or by edge waves interacting with the normal swell.

\section{CONCLUSIONS}

The shore-normal zones and shore-parallel bands of rippled coarse-grained sediment in Monterey Bay hold key evidence of ongoing shoreline erosion in the area. Erosion results from a eustatic sea level rise after the last glacial low stand 18 kya (Dupre and Clifton, 1979), coupled with subsidence and tilting of the offshore Salinas Block.

As sea level slowly rises the coastal dunes that fringe the southern Monterey Bay and the underlying beach and near shore deposits are eroded. This eroded material is reworked 
and the finest-grained material is transported offshore; the medium to fine-grained component is blown inland and the coarsest material remains on the beach (Cooper 1967). During periods of high waves coarse grained sand on the beach is transported across the shoreface to the inner continental shelf in channels formed by large scale rip currents. Simultaneously the storm surf scours the bay floor, thereby producing depressions parallel to the shoreline and forming lag deposits consisting of pebbles, shell fragments and coarse sand similar to those described in clifton et al. (1971). At this time the fine grained material is entrained as suspended sediment and is removed from the site. The ripples on the lag deposits and in the rip channels are formed between storm events. The large symmetrical shore parallel ripples found in bands and zones are oscillatory wave ripples with a tendency for ripple spacing to increase with decreasing depth (Clifton and Dingler, 1984). 


\section{REFERENCES CITED}

Arnal, R.E., Dittmer, E., and Shumaker, E, 1973, Sand Transport Studies in Monterey Bay, California, Technical Publication 73-5, Annual Report, Part 5, Moss Landing Marine Laboratories, Moss Landing, CA. $71 \mathrm{pp}$.

Bowen, A.J., 1969, Rip currents, 1: theoretical investigations, Journal of Geophysical Res,. 74 , p. 54675478 .

Bowen, A.J., Inman, D.L., 1969, Rip currents, 2: laboratory and field observations: Journal of Geophysical Res. 74, p. 5479-5490

Breaker, I.C. and Broenkow, W.W., 1989, The Circulation of Monterey Bay and Related Processes, Moss Landing Laboratories Technical Pub. 89-1, 80 pp.

Cacchione, D.A., Drake, D.E., Grant, W.D., and Tate, E.B., 1984, Rippled Scour Depressions on The Inner Continental Shelf off central California, Journal of sediment Petrology, Vol. 54, No 4 December, 1984, p. 1280-1291.

Chin, John L., Clifton, H. Edward, and Mullins, Henry T., 1988, Seismic Stratigraphy and Late Quaternary Shelf History, South-Central Monterey Bay, California, Marine Geology, 81 p. 137-157.

Clifton, H.E., Hunter, R.E., and Phillips, R.L., 1971, Depositional structures and precesses in the high-energy nonbarred nearshore, j. Sediment Petrol., 51, p. 651-670.

Clifton, H.E., Dingler, J.R., 1984, Wave-Formed structures and Paleoenvironmental Reconstruction, Marine Geology, 60, p. 165-198.

Cooper, W.S., 1967, Coastal Sand Dunes of Monterey Bay California, Memoir of the Geological Society of America, No $104,71 \mathrm{pp}$.

Cowell, P.J., 1986, Australian "Mega Rip" Study, 86 EOS Transactions, American Geophysical Union, Volume 67 Numbers 1-25, p. 449 
de Raaf, J.F.M., de Boersma, J.R. and Van Gelder, A., 1977, Wave-generated structures and sequences from a shallow marine succession. Lower Carboniferous, county cork, Ireland. Sedimentology V 24, p. 451-483.

Dittmer, E.R., 1972, A Sediment Budget Analysis of Monterey Bay, MS Thesis SJSU. $132 \mathrm{pp}$.

Dorman, C.E., 1968, The Southern Monterey Bay Littoral Cell: A Preliminary sediment Budget Study, M.S. Thesis Naval Postgraduate School, Monterey California, 234 pp.

Dupre, W.R., 1975, Quaternary History of the Watsonville lowlands, north-central Monterey Bay region, Dissertation, Stanford University. $145 \mathrm{pp}$.

Dupre, W.R., and Clifton, H.E., 1979, Modern and Ancient Coastal Sedimentary Facies Monterey Bay, California, Field trip guidebook for the Geological society of America Cordilleran Section, p. 34-37.

Greene, Gary B., 1977, Geology of the Monterey Bay Region, U.S. Department of the Interior Geological Survey, open File Report 77-718. 153 pp.

Griggs, G.B.,1974, Nearshore current Patterns along the Central California Coast, Estuarine and Coastal Marine Science 2, p. 395-405.

Griggs, G.B. \& Jones, B.D., 1985, Erosion Along An "Equilibrium Coastline" Southern Monterey Bay, California, California's Battered coast, Proceedings from a Conference on Coastal Erosion, San Diego, February 6-8, 1985 , p. 102-119

Griggs, G.B. \& Savoy, L., 1985, Living with the California Coast, Duke University Press, Durham, N.C. p. 178-295.

Harms, J.C., Southard, J.B., spearing, D.R. and Walker, R.G., 1975, Depositional Environments As Interpreted from Primary sedimentary structures and stratification Sequences, SEPM Short Course No. 2 .

Hunter, R.E., Dingler, J.R., Anima, R,J. and Richmond, E.M. 1988, Coarse-sediment Bands on The Inner Shelf of Southern Monterey Bay, California, Marine Geology, 80, p. 81-98. 
Inman, D.I., 1957, Wave Generated Ripples in Nearshore Sands, Contributions from the Scripps Institution of oceanography, New Series No. 947, p. 645-711.

Inman, D.L., 1963, Ocean Waves and Associated Currents, Marine Geology, Second, Edition, Harper and Row Pub., p. $49-81$.

Johnson, R., Foxx, M., Harris, V. and Reid, T., 1987, Shoreline recession study, Marina Dunes plan supporting technical studies, Marina Coastal Zone Planning Task Force, November 1987. $65 \mathrm{pp}$.

Jones, G.D., 1983, Coastal erosion at selected points on Southern Monterey Bay, Senior thesis, Earth Sciences Dept. University of California, Santa Cruz, $47 \mathrm{pp}$.

Komar, P.D., 1976, Beach Processes and Sedimentation, Prentice-Hall, Inc., Englewood Cliffs, N.J., 429 pp.

Komar, P.D. and Miller, M.C., 1975, The Initiation of Oscillatory Ripple Marks and the Development of Plane-Bed at High shear Stresses Under Waves, Journal of Sedimentary Petrology, Vol. 45, No. a3, p. 697-703.

MC Gee, Timothy, 1986, Coastal Erosion along Monterey Bay, unpublished M.S. thesis, Naval Postgraduate School, Monterey Ca., p 9-58.

Miall, A.D.,1985, Principles of Sedimentary Basin Analysis, Springer-Verlag New York. p 162.

National Oceanic and Atmospheric Administration (NOAA), 1983, Tide Tables, Pacific coast of North and South America, USA, Department of Commerce, Rockville Md.

Niedoroda, A.W., Swift, D.J.P., Hopkins, T.S., Chen-Mean, M., 1984, Shoreface Morphodynamics on Wave-Dominated Coasts, Marine Geology, 60 p. 331-354.

oradiwe, E.N., 1986, Sediment Budget for Monterey Bay, M.S. Thesis, Naval Postgraduate School Monterey CA. 101 pp.

Reimintz, E., Toimil, L.J., Shepard, F.P., Guieterrez-Estrada, M., 1976, Possible Rip Current origin for Bottom Ripple Zones to 30-M Depth, Geology, V 4, p. 395-400.

Sklavidis, A.I., Williams, R. Lima Blanco, 1985, Coastal Erosion Along Monterey Bay, Unpublished M.S. Thesis, 
Naval Postgraduate School Monterey CA. 107 pp.

Smith, O.P., 1983, Reconnaissance Report on Coastal Erosion at Fort ord, California, U.S. Army Corps of Engineers, Miscellaneous Paper CERC-83-10. $63 \mathrm{pp}$.

Thompson, W.C. 1977, Notes on Coast Erosion Between Monterey Harbor and Moss Landing, Consultant in Oceanography, Background Report, 20 pp.

Thompson, W.C. 1981, Coastal erosion and runup on the Phillips Petroleum property, Southern Monterey Bay: Unpublished consulting report for Ponderosa Homes, $36 \mathrm{pp}$.

Thornton, E.B. 1984, Examination of Coastal erosion at the Philitps property, Southern Monterey Bay, Unpublished report, $\mathrm{p} 8$.

Tinsley, J.C., 1975, Quaternary geology of Northern Salinas Valley, Monterey County, CA, Ph.D. Dissertation, Stanford University. $196 \mathrm{pp}$.

Welday, E.E., 1972, The Southern Monterey Bay Littoral \& Coastal Environment and the Impact of Sand Mining, California Division of Mines and Geology $43 \mathrm{pp}$.

Wiegel, R.L., 1965, Oceanographical Engineering, Prentice Hall, Inc. Englewood Cliffs, N.J., p. 341-381. 


\section{Appendices}

The following appendices contain the navigational data recorded or all of the cruises and wave data for the seven months of this study. 


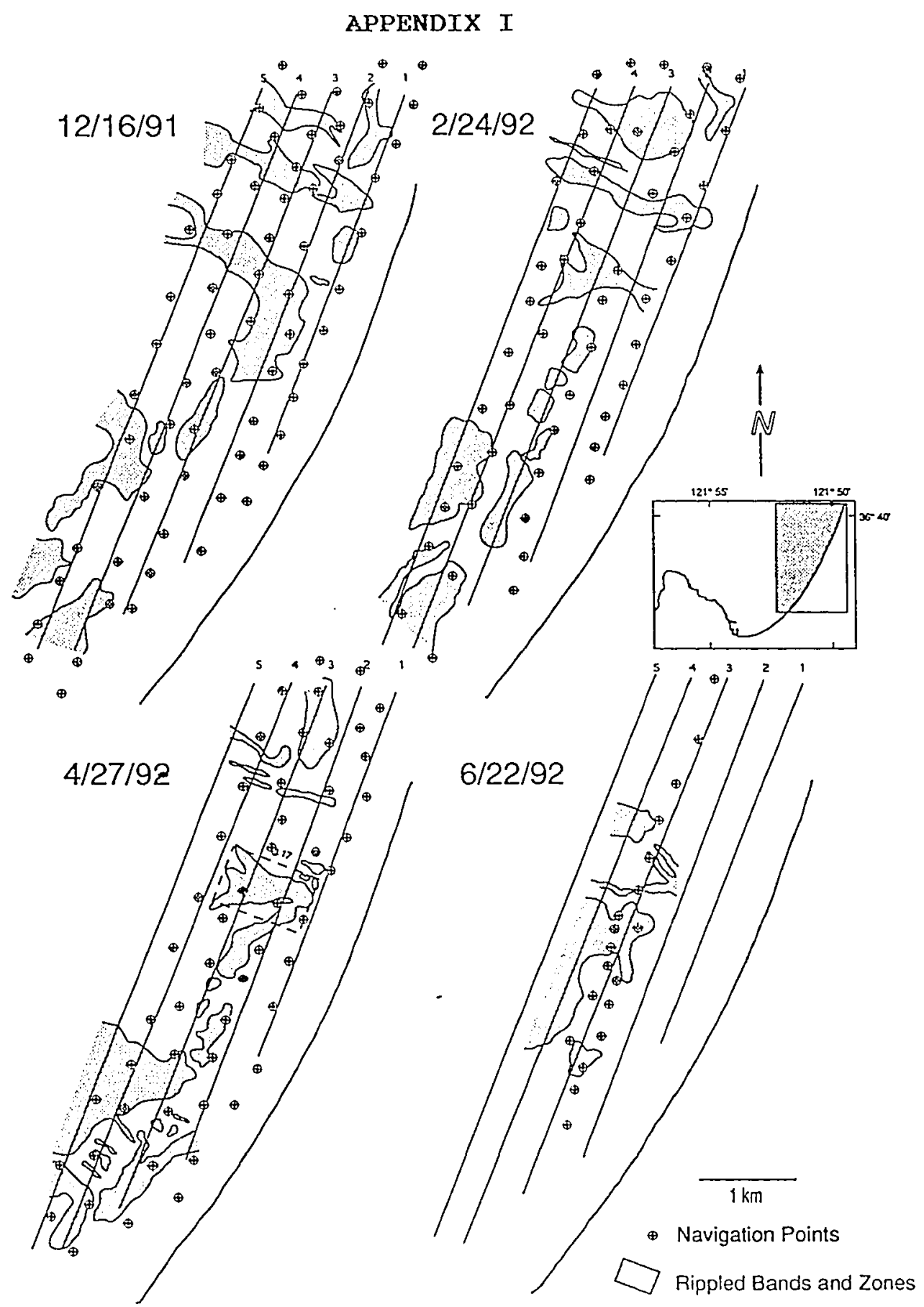

Navigation lires plotted with rippled bands and zones of coarse grained sediment. 


\begin{tabular}{|c|c|c|c|c|c|c|c|}
\hline & & ' & $\begin{array}{l}\text { APPEND } \\
\text { NAVIGATION } \\
\text { DECEMBER }\end{array}$ & $\begin{array}{l}|X| \\
\text { LOGS } \\
2,1991\end{array}$ & & & \\
\hline $\begin{array}{c}\text { line } 1 \\
\text { lat }\end{array}$ & & Boat Speed & & line 2 & & Boat Speed & \\
\hline $\begin{array}{cl}\text { lat } \\
36 & 38.30\end{array}$ & Iong & knots & comments & lat & long & knots & comments \\
\hline $\begin{array}{ll}36 & 38.30 \\
36 & 38.48\end{array}$ & 12150.47 & 2.9 & fish in & 3640.70 & 12149.46 & 3.2 & begin line 2 \\
\hline $\begin{array}{ll}36 & 38.48 \\
36 & 38.77\end{array}$ & 12150.43 & 2.9 & begin line 1 & 3640.47 & 12149.61 & 3.2 & \\
\hline 3638.77 & 12150.34 & 2.9 & & 3640.13 & 12149.72 & 3 & \\
\hline 3638.92 & 12150.25 & 2.9 & & 3639.88 & 12149.81 & 3.3 & \\
\hline 3638.99 & 12150.21 & 2.9 & & 3639.64 & 12149.95 & 2.8 & \\
\hline 3699.24 & 12150.10 & 3.2 & & $36 \quad 39.40$ & 12149.05 & 3.2 & \\
\hline 3639.46 & 12150.00 & 2.9 & & 3639.16 & 12150.18 & 2.9 & \\
\hline 3639.70 & 12149.88 & 2.7 & current noted & 3638.95 & 12150.30 & 3.1 & \\
\hline 3639.93 & 12149.79 & 2.8 & & 3638.70 & 12150.41 & 3 & \\
\hline 3640.17 & 12149.67 & 3.1 & & 3638.46 & 12150.52 & 3 & \\
\hline 3640.40 & 12149.56 & 2.8 & & 3638.23 & 12150.62 & 3 & \\
\hline 3640.63 & 12149.42 & 3 & & 3638.08 & 12150.69 & 3 & end of line 2 \\
\hline 3640.71 & 12149.37 & 3 & end of line & & & & \\
\hline line 3 & & Eoat Spant & & line 4 & & Boat Speed & \\
\hline lat & long & knots & comments & lat & long & knots & comments \\
\hline 3637.87 & 12150.91 & 2.9 & begin line 3 & 3640.71 & 12149.81 & 3 & \\
\hline 3638.26 & 12150.82 & 3 & & 3640.43 & 12149.92 & 3.1 & \\
\hline 3638.40 & 12150.71 & 2.9 & & 3640.19 & 12150.04 & 3.1 & \\
\hline 3638.65 & 12150.62 & 3.1 & & 3640.94 & 12150.15 & 3.1 & \\
\hline $36 \quad 38.90$ & $121 \quad 50.51$ & 3.1 & & 3639.69 & 12150.24 & 3 & \\
\hline 3639.11 & 12150.44 & 2.7 & current noted & 3639.44 & 12150.35 & 3 & \\
\hline $36 \quad 39.35$ & 12150.34 & 2.9 & & 3639.20 & 121.50 .46 & 3.2 & \\
\hline 3638.58 & 12150.24 & 2.9 & change & $36 \quad 38.97$ & 12150.55 & 2.9 & \\
\hline 3639.76 & 12150.17 & 3 & & 3638.74 & 12150.65 & 2.7 & \\
\hline $36 \quad 39.99$ & 12150.06 & 3.2 & & 3638.53 & 12150.73 & 2.6 & \\
\hline 3640.26 & 12149.93 & 3 & & 3638.31 & 12150.84 & 2.8 & \\
\hline $36 \quad 40.44$ & 121.49 .83 & 3 & & $36 \quad 38.07$ & 12150.92 & 2.6 & \\
\hline $36 \quad 40.67$ & 12149.66 & 3.8 & end of line 3 & $36 \quad 37.91$ & 12151.01 & 2.8 & end of line 4 \\
\hline line 5 & & Boat Speed & & & & & \\
\hline lat & long & knots & commonts & & & & \\
\hline 3637.87 & 12151.11 & 2.6 & begin line 5 & & & & \\
\hline 3638.12 & 12151.00 & 2.7 & - & & & & \\
\hline $36 \quad 38.39$ & 12159.89 & 3.1 & & & & & \\
\hline 3638.60 & 12150.81 & 3.1 & & & & & \\
\hline 3638.83 & 12150.72 & 3.2 & & & & & \\
\hline 3639.06 & 12150.62 & 2.9 & & & & & \\
\hline 3639.27 & 12150.51 & 2.8 & & & & & \\
\hline 3639.50 & 12150.41 & 2.8 & & & & & \\
\hline 3639.71 & 12150.30 & 2.8 & & & & & \\
\hline 3639.93 & 12150.18 & 2.8 & & & & & \\
\hline 3640.14 & 12150.06 & 2.7 & current noted & & & & \\
\hline $36 \quad 40.36$ & 12149.96 & 2.9 & & & & & \\
\hline 3640.55 & 12149.84 & 2.9 & & & & & \\
\hline 3640.69 & 12149.76 & 3 & & & & & \\
\hline
\end{tabular}

Data recorded at 5 min. intervals 
,

line 1 latt long

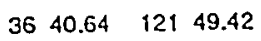
$\begin{array}{llll}36 & 40.41 & 121 & 49.43\end{array}$

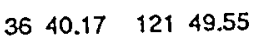
$\begin{array}{llll}36 & 39.92 & 121 & 49.70\end{array}$ $\begin{array}{llll}36 & 39.82 & 121 & 49.85\end{array}$ $\begin{array}{llll}36 & 39.67 \quad 121 & 49.98\end{array}$ $\begin{array}{llll}36 & 39.43 & 121 & 50.10\end{array}$ $\begin{array}{llll}36 & 39.20 & 121 & 50.23\end{array}$ $\begin{array}{llll}36 & 38.98 & 121 & 50.38\end{array}$ $\begin{array}{llll}36 & 38.73 & 121 & 50.49\end{array}$ $\begin{array}{llll}36 & 38.46 \quad 121 & 50.53\end{array}$ $\begin{array}{llll}36 & 38.39 & 121 & 50.61\end{array}$
APPENDIX ! NAVIGATION LOGS FEBRUARY 24, 1992

$\begin{array}{cc}\begin{array}{c}\text { Boat Speed } \\ \text { knots }\end{array} & \\ 3 & \text { comments } \\ 3 & \\ 3 & \\ 3 & \\ 3.3 & \\ 3.1 & \\ 2.9 & \text { boat slowed } \\ 3.1 & \\ 3.2 & \\ 3.2 & \\ 3 & \end{array}$

\section{line 2}

lat $36 \quad 37.89$ 3638.13 $36 \quad 39.39$

$36 \quad 38.39$

$36 \quad 38.44$

3638.68

3638.96

3639.83

3639.48

$36 \quad 39.72$

3639.98

3639.98

3640.21

3640.45

3640.69

3640.82

line

lat

$36 \quad 37.93$

$36 \quad 37.19$

$36 \quad 38.45$

$36 \quad 38.74$

$36 \quad 38.99$

$36 \quad 39.25$

$36 \quad 39.51$

$36 \quad 39.79$

3640.06

$36 \quad 40.31$

3640.54

3640.78 long

12150.90

12150.83

12150.78

12150.77

12150.77

12150.66

12150.57

12150.48

12150.39

12150.25

12150.20

12150.10

12149.96

12149.79

12149.65

12149.50
Boat Speed

knots

3

3

3 paper change

2.9

2.9 back on line

2.9

2.9

3.1

3.1

3

3.2

3.2

3.2

3.2

3.2

3.2

Boat Speed

long

12151.01

12150.94

12150.88

12150.77

12150.71

12150.60

12150.56

12150.45

12150.31

12150.20

12150.03

12149.88 comments knots

3

3

3

3.2

3.2

3

3

3.1

3.2

3.4

3.1

3.1

Data recorded at 5 min. intervals 


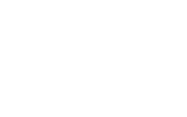

line 1

$36 \quad 38.33$

$36 \quad 38.57$

3638.87

$36 \quad 39.05$

$36 \quad 39.30$

$36 \quad 39.54$

$36 \quad 39.79$

$36 \quad 40.01$

$36 \quad 40.24$

$\begin{array}{ll}36 & 40.49\end{array}$

3640.70

line 3

\begin{tabular}{lr}
36 & lat \\
36 & 38.84 \\
\hline
\end{tabular}

$\begin{array}{ll}36 & 38.35\end{array}$

$36 \quad 38.63$

$36 \quad 38.90$

$36 \quad 39.15$

$\begin{array}{ll}36 & 38.33\end{array}$

$36 \quad 38.58$

$36 \quad 38.82$

36.39 .06

$\begin{array}{ll}36 & 39.30\end{array}$

$\begin{array}{ll}36 & 39.52\end{array}$

$36 \quad 39.76$

$36 \quad 39.99$

$36 \quad 40.23$

उ6 40.47

3640.68
APPENDIX I

NAVIGATION LOGS

APRIL 27, 1992

\begin{tabular}{ccc}
\multicolumn{2}{c}{ long } & $\begin{array}{c}\text { Boat Speed } \\
\text { knots }\end{array}$ \\
121 & 50.48 & 3 \\
121 & 50.39 & 3 \\
121 & 50.27 & 3 \\
121 & 50.15 & 3 \\
121 & 50.03 & 3 \\
121 & 49.92 & 3 \\
121 & 49.81 & 3 \\
121 & 49.68 & 3.1 \\
121 & 49.57 & 3 \\
121 & 49.47 & 3 \\
121 & 49.37 & 3
\end{tabular}

Boat Speed

knots

long

12150.91

12150.87

12150.78

12150.75

12150.67

12150.59

12150.75

12150.72

12150.66

12150.55

12150.43

12150.30

12150.19

12150.05

$121 \quad 49.92$

$121 \quad 49.78$

12149.66

line 5

$\begin{array}{lll}36 & 37.87\end{array}$

$36 \quad 38.10$

$36 \quad 38.34$

$\begin{array}{ccc}\text { long } & \begin{array}{c}\text { Boat Speed } \\ \text { knots }\end{array} \\ 121 & 51.11 & 3 \\ 121 & 51.03 & 3 \\ 121 & 50.94 & 3\end{array}$

$36 \quad 38.95$ line 2

comments

lat

$36 \quad 40.70$

$36 \quad 40.45$

3640.20

3639.95

$36 \quad 39.70$

$36 \quad 39.45$

$36 \quad 39.21$

3638.71

$36 \quad 38.45$

$36 \quad 38.18$

3638.08

long

12149.47

$121 \quad 49.59$

12149.70

12149.81

12149.94

12150.09

12150.20

12150.31

12150.41

12150.53

12150.64

12150.68

line 4
lat

$36 \quad 40.69$

36.40 .45

$36 \quad 40.24$

$36 \quad 39.98$

$36 \quad 39.75$

$36 \quad 39.53$

off line

back on line

3639.27

3939.05

$36 \quad 38.82$

$36 \quad 38.57$

$36 \quad 38.34$

$36 \quad 38.08$

$36 \quad 37.92$

long

12149.83

$121 \quad 49.99$

12150.13

$121 \quad 50.22$

$121 \quad 50.32$

12150.41

12150.50

12150.61

12150.71

$121 \quad 50.80$

12150.88

12150.98

12151.04
Boat Speed
knots comments

3

3

3

3

3

3

3

3

3

3

3

3

Boat Speed

knots

comments

3

3

3

3

3

3

3

3

3

3

3

3 


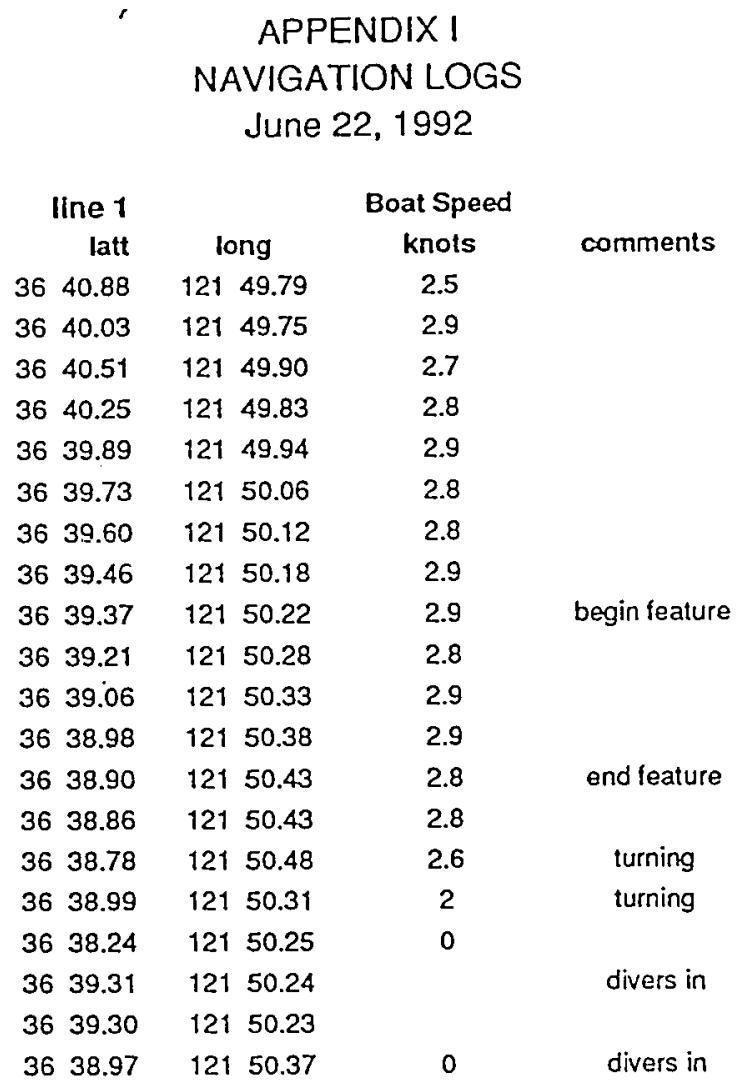

Data recorded at $5 \mathrm{~min}$. intervals 


\section{APPENDIX II}

from Coastal Data Information Program

U.S. Army corps of Engineers and California Department of Boating and Waterways

Spectral plots have are provided to indicate periods of interest and have no scale. All of the information was recorded at the Marina Array. 
APPENDIX II

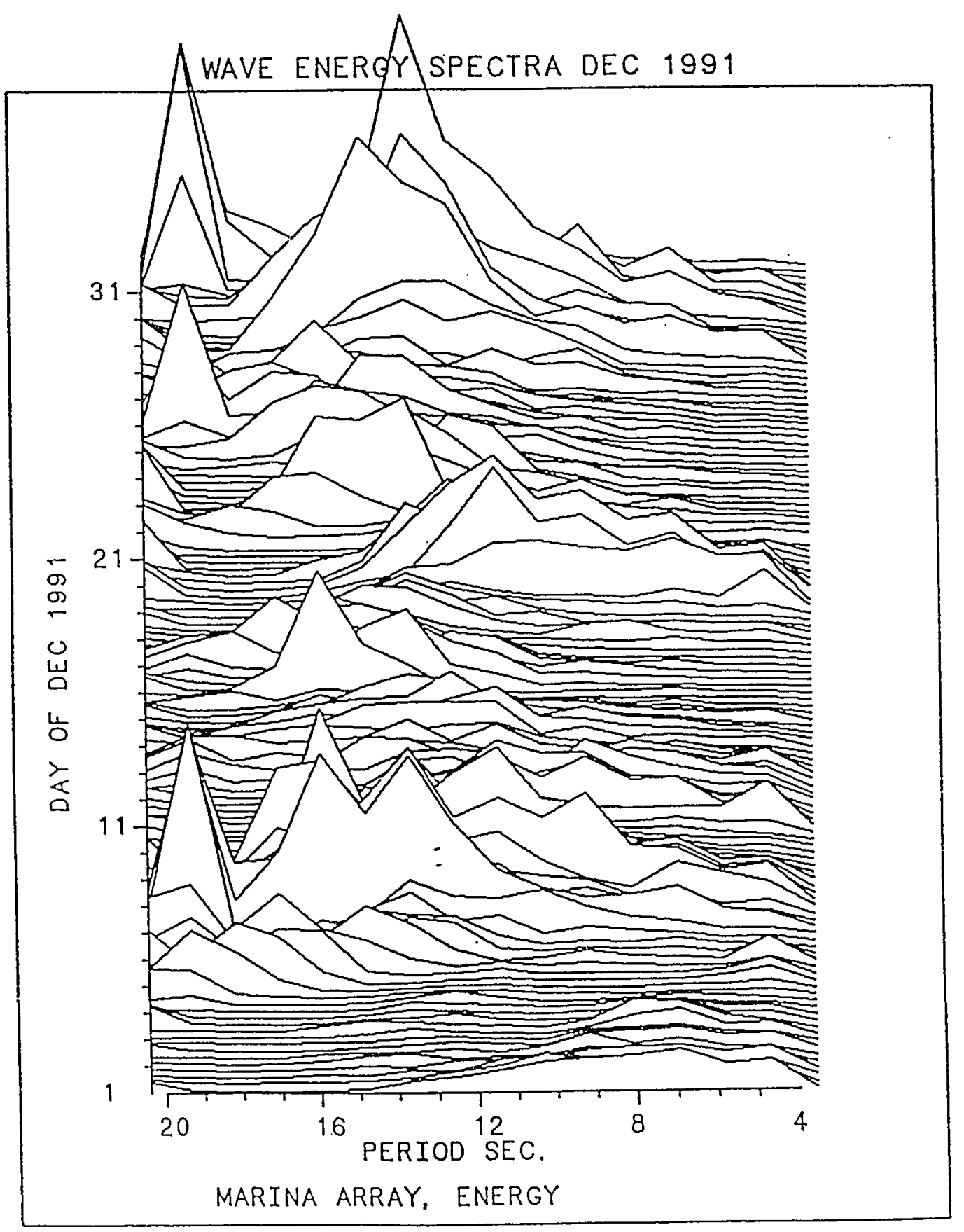


APPENDIX II

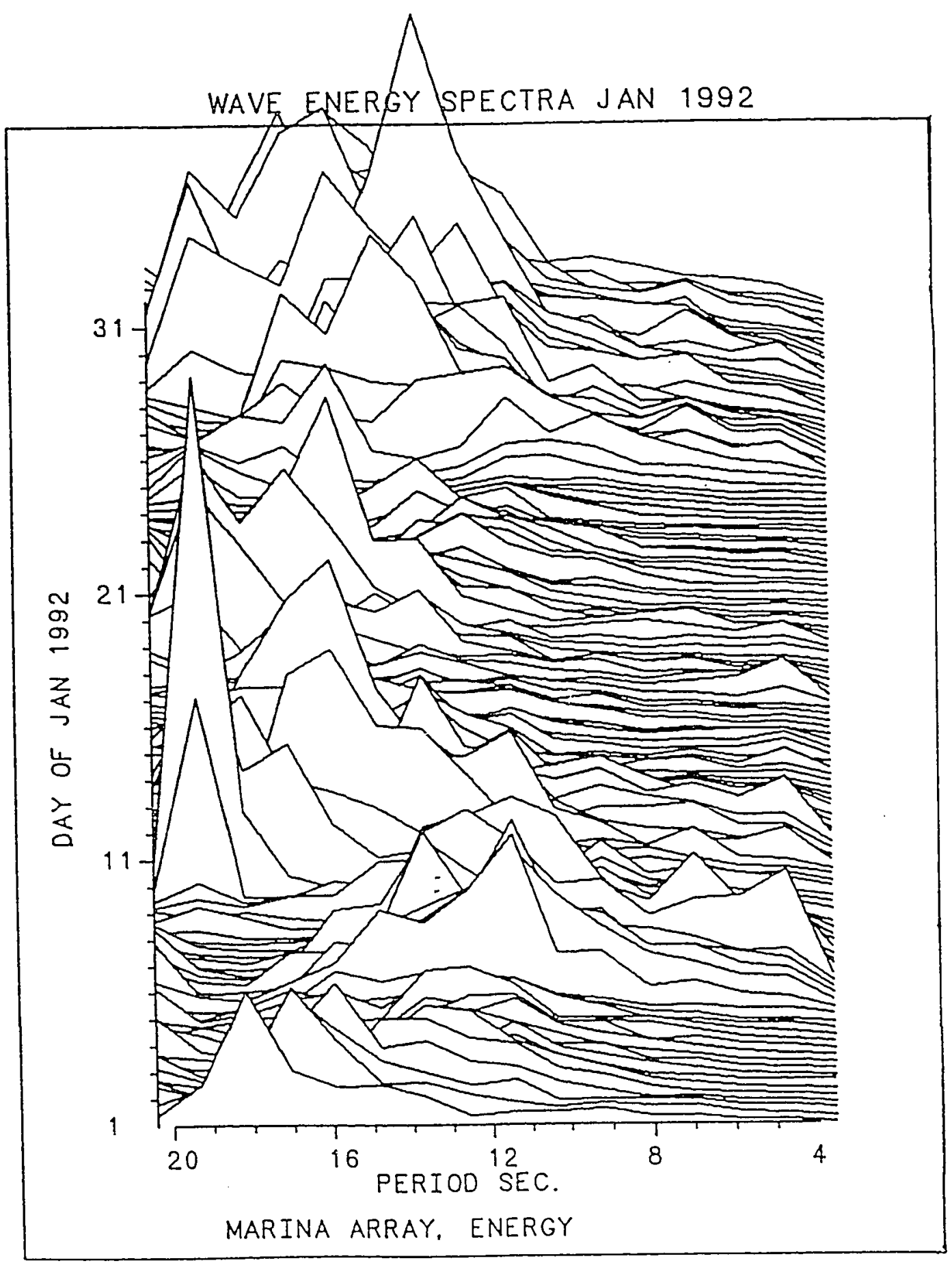


APPENDTX II

WAVE ENERGY SPECTRA FEB 1992

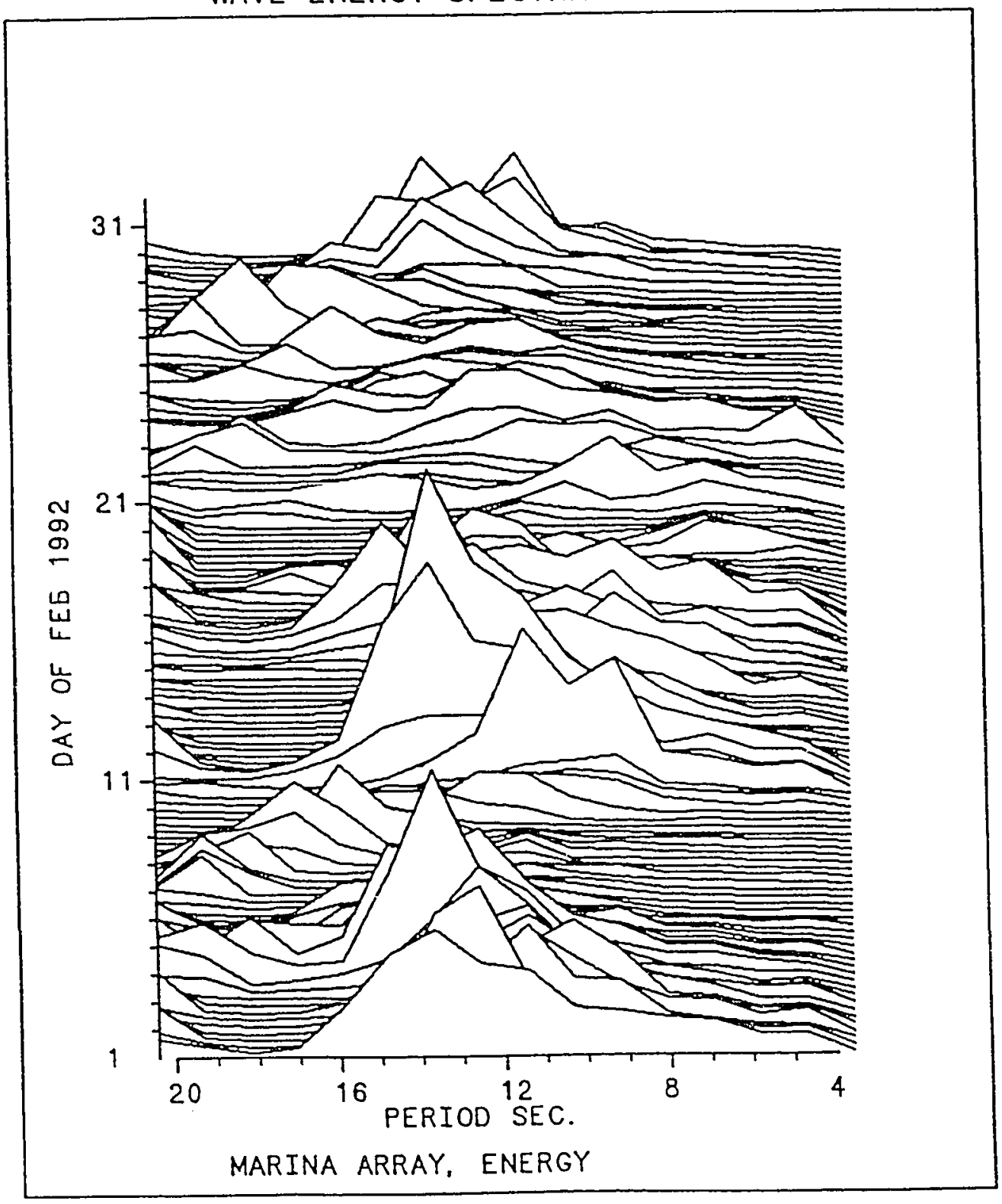


WAVE ENERGY SPECTRA MAR 1992

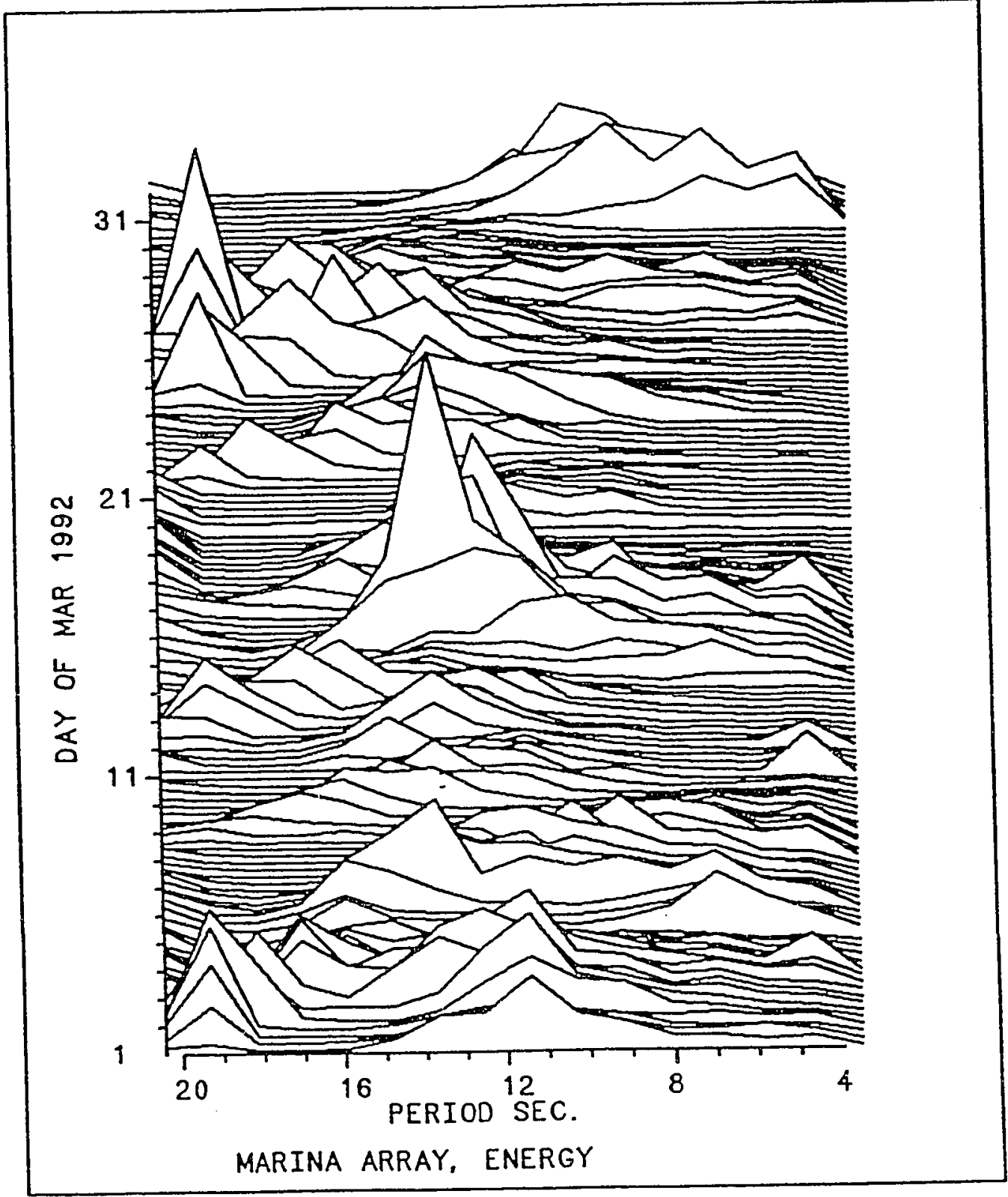


APPENDIX II

WAVE ENERGY SPECTRA APR 1992

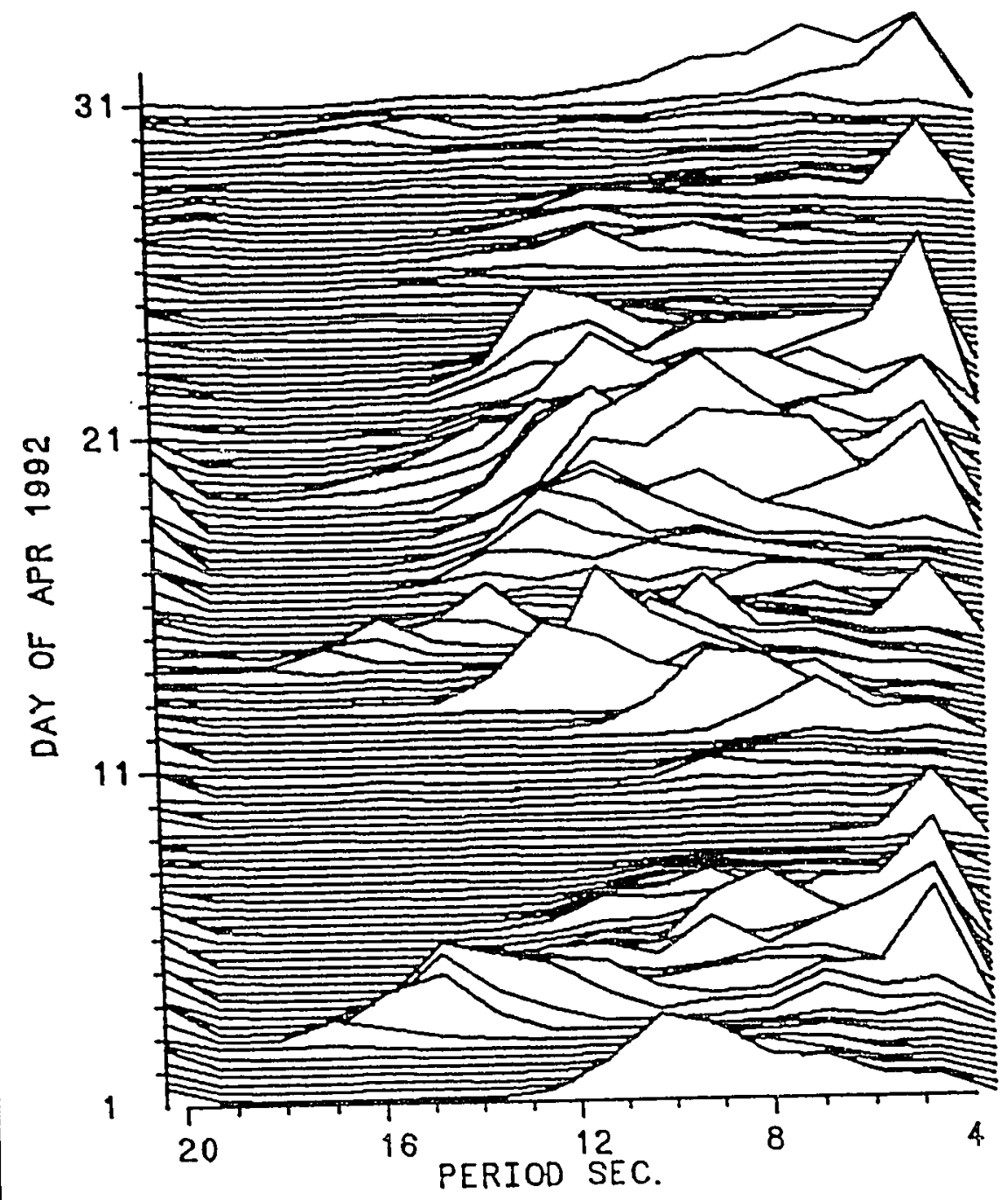

MARINA ARRAY, ENERGY 


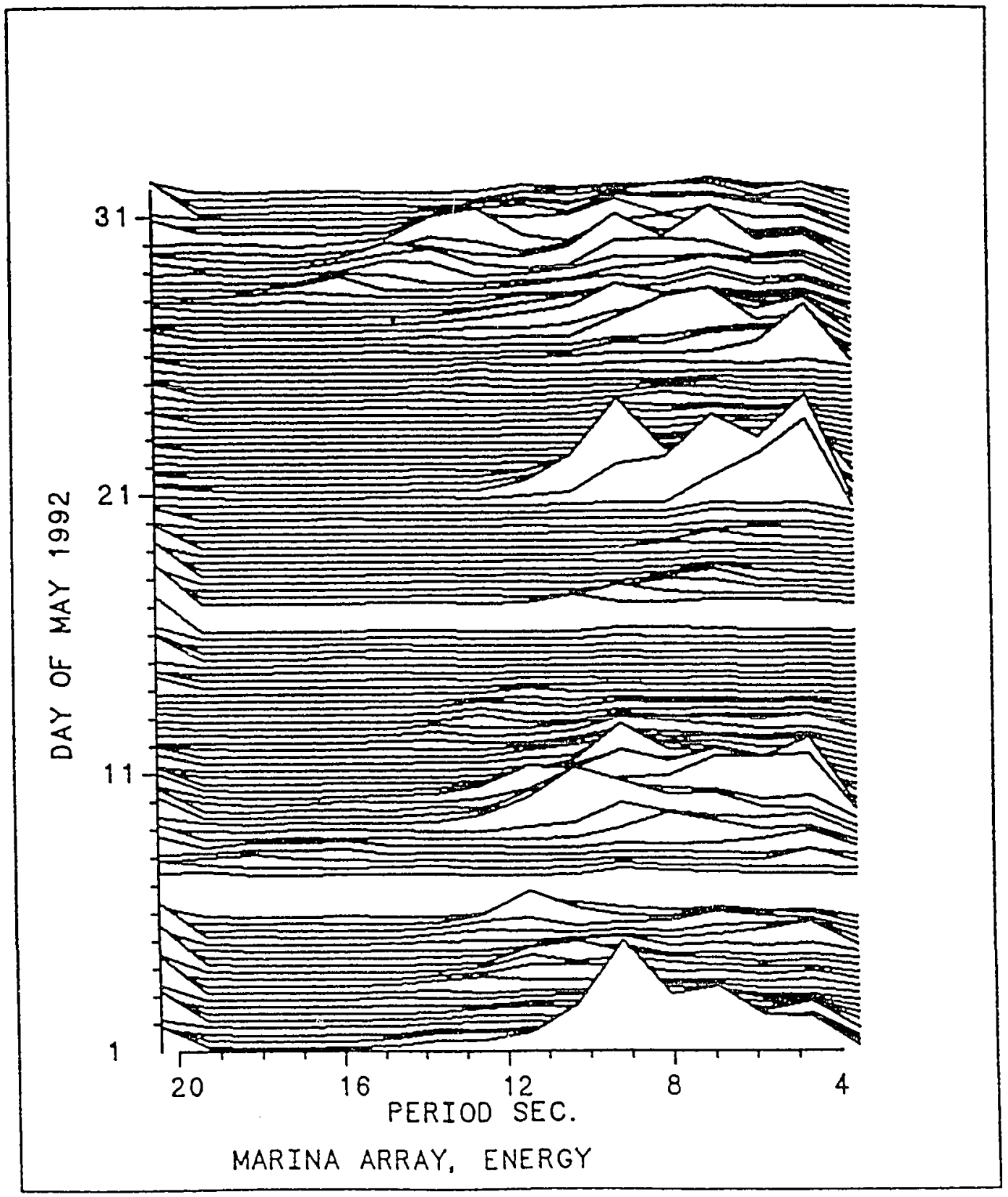


APPENDIX II

WAVE ENERGY SPECTRA JUN 1992

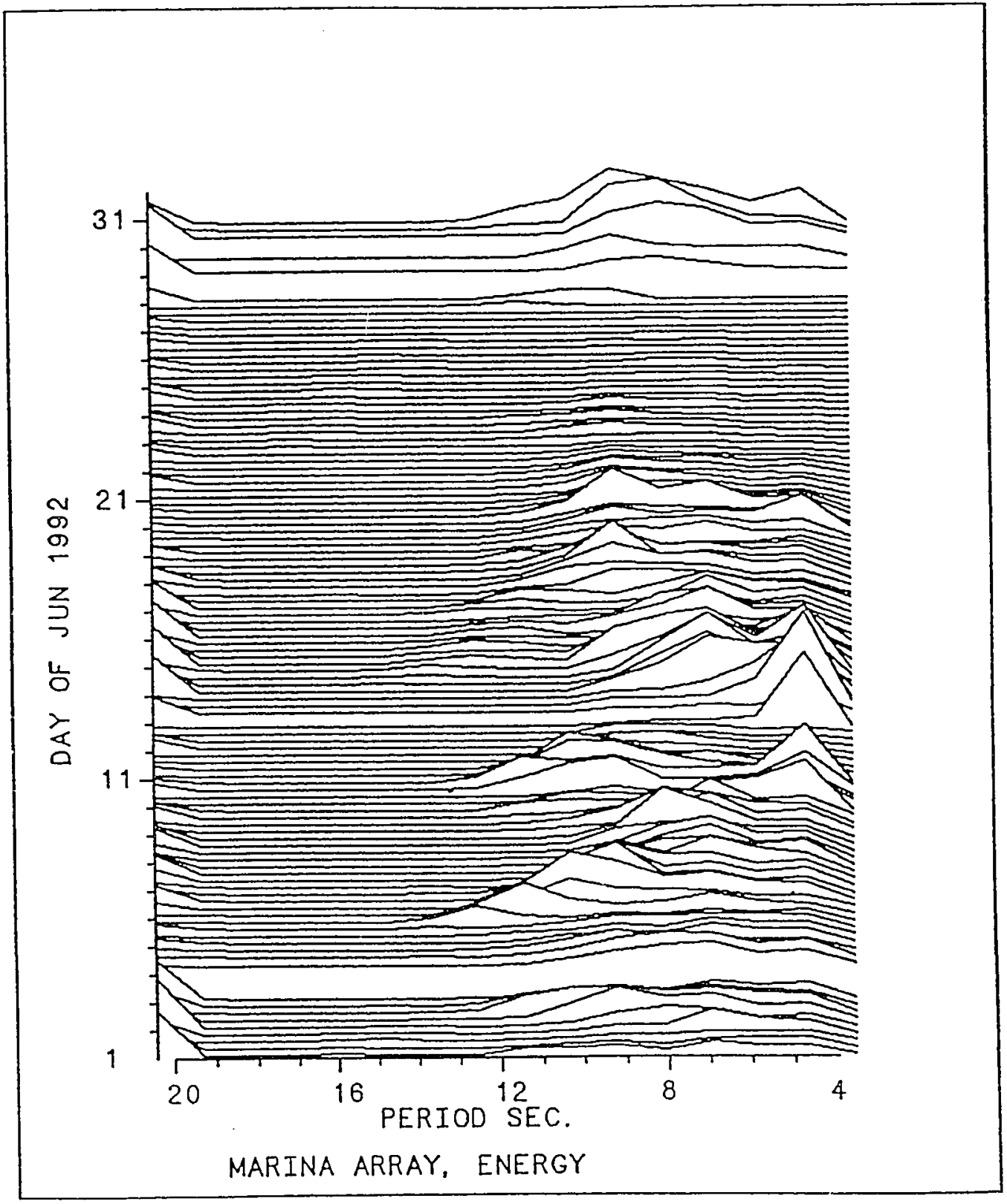

